\title{
Factors Determining the Success and Failure of eHealth Interventions: Systematic Review of the Literature
}

\author{
Conceição Granja ${ }^{1}$, PhD; Wouter Janssen ${ }^{2}$, MSc; Monika Alise Johansen ${ }^{1,2}, \mathrm{PhD}$ \\ ${ }^{1}$ Future Journal, Norwegian Centre for E-health Research, Troms $\emptyset$, Norway \\ ${ }^{2}$ Telemedicine and E-health Research Group, University of Troms $\varnothing$-The Artic University of Norway, Troms $\varnothing$, Norway
}

Corresponding Author:

Conceição Granja, PhD

Future Journal

Norwegian Centre for E-health Research

PO Box 35

Troms $\varnothing$, N-9038 Troms $\varnothing$

Norway

Phone: 4790817344

Email: conceicao.granja@ehealthresearch.no

\section{Abstract}

Background: eHealth has an enormous potential to improve healthcare cost, effectiveness, and quality of care. However, there seems to be a gap between the foreseen benefits of research and clinical reality.

Objective: Our objective was to systematically review the factors influencing the outcome of eHealth interventions in terms of success and failure.

Methods: We searched the PubMed database for original peer-reviewed studies on implemented eHealth tools that reported on the factors for the success or failure, or both, of the intervention. We conducted the systematic review by following the patient, intervention, comparison, and outcome framework, with 2 of the authors independently reviewing the abstract and full text of the articles. We collected data using standardized forms that reflected the categorization model used in the qualitative analysis of the outcomes reported in the included articles.

Results: Among the 903 identified articles, a total of 221 studies complied with the inclusion criteria. The studies were heterogeneous by country, type of eHealth intervention, method of implementation, and reporting perspectives. The article frequency analysis did not show a significant discrepancy between the number of reports on failure (392/844, 46.5\%) and on success $(452 / 844,53.6 \%)$. The qualitative analysis identified 27 categories that represented the factors for success or failure of eHealth interventions. A quantitative analysis of the results revealed the category quality of healthcare $(n=55)$ as the most mentioned as contributing to the success of eHealth interventions, and the category costs $(n=42)$ as the most mentioned as contributing to failure. For the category with the highest unique article frequency, workflow ( $\mathrm{n}=51)$, we conducted a full-text review. The analysis of the 23 articles that met the inclusion criteria identified 6 barriers related to workflow: workload (n=12), role definition $(n=7)$, undermining of face-to-face communication $(n=6)$, workflow disruption $(n=6)$, alignment with clinical processes $(n=2)$, and staff turnover $(n=1)$.

Conclusions: The reviewed literature suggested that, to increase the likelihood of success of eHealth interventions, future research must ensure a positive impact in the quality of care, with particular attention given to improved diagnosis, clinical management, and patient-centered care. There is a critical need to perform in-depth studies of the workflow $(\mathrm{s})$ that the intervention will support and to perceive the clinical processes involved.

(J Med Internet Res 2018;20(5):e10235) doi: $\underline{\text { 10.2196/10235 }}$

\section{KEYWORDS}

telemedicine; eHealth; medical informatics; systematic review; success; failure 


\section{Introduction}

In the last decades, it has been a challenge for policy makers to ensure access to healthcare to populations living in rural and remote areas [1]. Additionally, global demographic trends, such as the increasing number of elderly people, have been changing healthcare delivery due to a growing demand for long-term care and increasing costs [2-5]. Against this background, eHealth has been presented as a solution [6-8]. In the context of this study, we define eHealth as the use of information and communication technology in healthcare.

A vast amount of eHealth interventions have been reported to fail during clinical implementation $[9,10]$. Tanriverdi and Iacono [8] demonstrated that a considerable amount of research with promising results did not contribute to clinical practice. Berg [11] stated more specifically that $75 \%$ of implemented eHealth should be considered a failure.

According to Bashshur et al [12], the assessment of eHealth interventions rests on three pillars of care: (1) access, (2) quality, and (3) cost containment. They describe these three pillars as the promises that eHealth interventions are required to fulfill to attain a successful outcome and, indeed, that each of these promises must be met. Considering the aforementioned reports on the failure of eHealth interventions [8-11], it appears reasonable to assume that the promises represented by these three pillars are not often accomplished.

To improve the success of eHealth, it is important to identify the factors that can influence, positively or negatively, the outcome of the intervention. Such factors can vary from project-specific to recurring issues, with the three pillars proposed by Bashshur et al [12] expected to have an important role in the success or failure of eHealth interventions. However, as the field of medical informatics is positioned between the fast-changing field of informatics and the rather conservative field of healthcare, organizational and operational aspects can be expected to play an important part in the outcome of eHealth interventions.

The overall aim of this study was to seek, through a systematic review, patterns in the assessment of eHealth intervention outcomes, and through these patterns to identify factors that can help explain why eHealth interventions fail or succeed in clinical practice. Therefore, we systematically searched for original studies that provide data to address the following key questions:

Key question 1: According to reports in abstracts, why are eHealth interventions failing to achieve the expected results and foreseen benefits? Specifically, (1) What are the major facilitators and barriers contributing to the implementation of eHealth? (2) How are these facilitators and barriers contributing to the adoption of eHealth? (3) Are the perceived facilitators and barriers to eHealth adoption similar among the study participants?

Key question 2: According to the literature, what is the most relevant factor regarding the possible outcome in terms of success or failure, or both? Specifically, in what manner is this factor affecting the adoption of eHealth?

\section{Methods}

This systematic review was guided by the Cochrane Handbook [13], and the reporting is based on the Preferred Reporting Items for Systematic reviews and Meta-Analyses (PRISMA) guidelines [14]. We established the review methods before conducting the review, and the reports did not justify any deviations from the protocol.

\section{Search Strategy}

We searched the PubMed database in October 2016 for original articles published in English up to this date. The main reason for using only the PubMed search engine was the availability of a vast amount of articles in eHealth research from both a medical and a sociological standpoint. In this way, we expected that we would find most of the relevant clinical outcomes for this study. Since the review focused on implemented eHealth tools, we did not consider the inclusion of articles from a technology perspective to be necessary. As this strategy proved to be useful, we searched no other academic databases.

We performed an initial search using the Medical Subject Heading (MeSH) telemedicine AND challenges, based on prior knowledge obtained from articles that referenced eHealth success or failure, which identified 658 articles. We evaluated the title and abstract of these articles and identified possible search terms. We determined the term "lessons" to be important and used it together with the previous search, identifying 63,299 articles. We analyzed the resulting articles to further specify the search terms and define the search string following the patient, intervention, comparison, and outcome (PICO) framework [15].

We based the search string on three classes of the PICO framework, since the class comparison did not apply to this study. We defined these classes as (P): healthcare; (I): eHealth; and $(\mathrm{O})$ : change, failure, or success. We combined all terms in each class with the logical operator OR and linked the classes using the logical operator AND. Over the course of refining the search results, we tried 2 search strings. In the first, we used the search terms extracted from the previous search to create a PICO scheme, constrained to the last 10 years, which identified 11,950 articles. In the second, we removed the time constraint and refined the search terms to focus on eHealth interventions that were used in actual clinical practice. This last search string (Textbox 1) was the one we used to retrieve the articles used in the review process. 
Textbox 1. The search string developed according to the patient, intervention, comparisona, and outcome (PICO) framework. Comparison (C) was not applicable to this study.

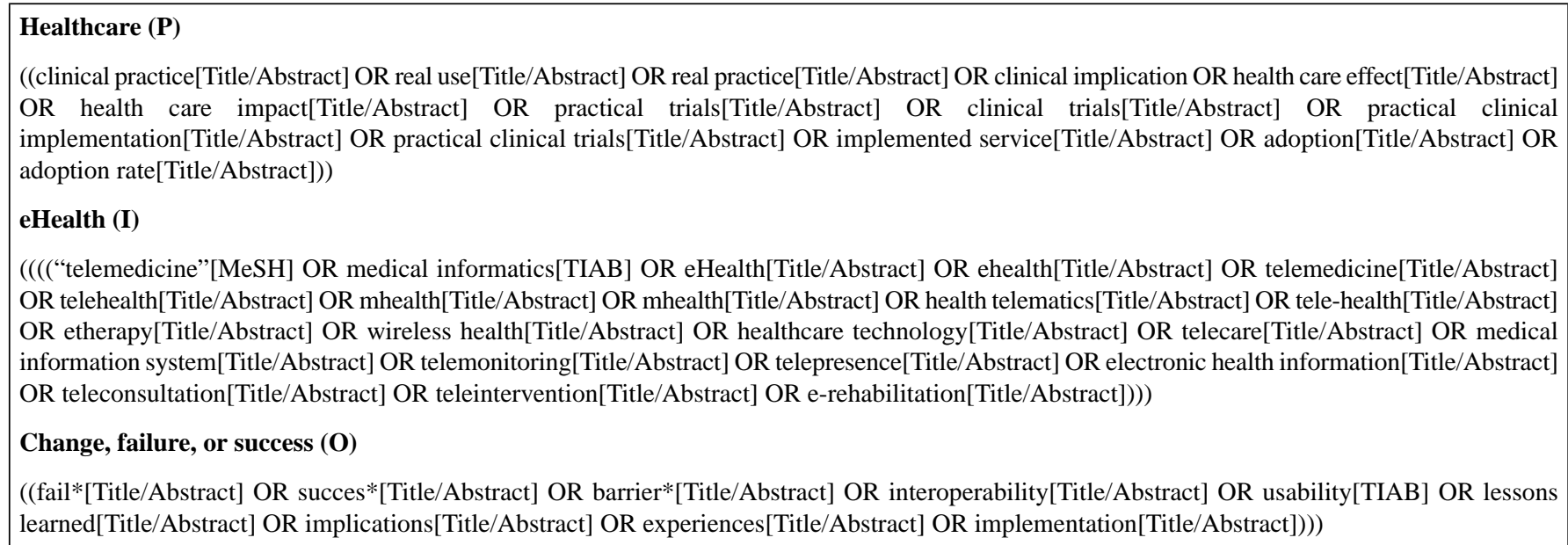

Textbox 2. Reading interpretation guidelines for the abstract review.

- Funding from government or tax money equals influence on society.

- $\quad$ Policies have an effect on both organizations and availability of tools for patients.

- Coordination and interoperability problems have consequences for patients, professionals, and systems.

- Extra (or changes in) work is seen as workflow.

- Safety is a relative term, interpreted as compared with traditional ways.

- Workforce problems are interpreted as change of workflow.

- (Un)familiarity with tools is seen as information technology training.

- Paternalism and empowerment is seen as empowerment or engagement.

- Medical (studies) students are seen as health professionals.

- Time is seen as either workflow or costs, depending on the context.

We included no articles based on hand searches of reference lists for the reasons outlined under Section 10.2.2.3 of the Cochrane Handbook [13]: "positive studies are more likely to be cited" and "retrieving literature by scanning reference lists may thus produce a biased sample of studies."

\section{Study Selection}

We analyzed the titles and abstracts of the articles that resulted from the final search string for inclusion according to the following predefined exclusion criteria: not an original work; unclear or no results; not research; not in English. We defined the exclusion criteria based on the key questions to include original studies in healthcare-related fields, with a focus on success and failure, that reported on a form of eHealth or medical informatics, but which did not have to be the main goal or result but should have been a key component. Textbox 2 lists the reading interpretation guidelines for the abstract review.

\section{Data Collection and Synthesis}

A qualitative analysis $[16,17]$ was carried out by 2 of the authors (CG and WJ) to classify the outcomes reported in the articles' abstract according to the following 3 levels.

\section{Category}

The category level was evidence that the factor described in the abstract contributed to the success or failure of the eHealth intervention. We defined categories based on the information found in the abstracts (presented in the Results section below). We chose this strategy to minimize the risk of bias, since predetermined categories could have led to a model that merely reflected our opinion.

\section{Success and Failure}

This level indicated whether the identified category was described as a success or failure factor reported in the intervention outcome narrative. As success and failure are important concepts of this study, we explain our considerations on the terms here.

We classified the factors in the categories as success if they were considered to facilitate the achievement of the study goals. The same category may have been described as success and failure in the same study by different participants. If specific features of an intervention were mentioned to be a success, we attributed these to success, even when the overall project was classified as failure. 
Textbox 3. Further exclusion criteria of articles.

- The category is mentioned only in the text.

- No extensive analysis of the category or reporting on the effects on eHealth outcomes is present.

- The category is only identified as relevant to the success or failure of eHealth, and no further considerations are taken.

- The article is not in English.

We classified the factors in the categories as failure if they were considered to be barriers to achieving the study goals. Different participants may have described the same category as success and failure in the same study. If specific features of an intervention were mentioned to be a failure factor, we attributed these to failure, even when the overall project was classified as success.

\section{Entity}

This level referred to the role of the study participant who reported the identified factor in the categories. The entities could assume the following values.

In this review, patients were people who received care. Therefore, we also included clients (ie, people with less-urgent problems) and customers (ie, people who were interested in monitoring their own health). This entity also included people who gave care to patients in a nonprofessional context (ie, parents, family, and friends).

Healthcare professionals comprised all people who provided care services in a professional context. This included physicians, nurses, therapists, mental health workers, and other professional groups trained in providing care. It did not necessarily have to be direct care, but they had to have been providing care to patients.

The health system included management and supporting staff, infrastructure, the technological health systems (both software and hardware), and ideological systems such as national health plans and systems.

The society value included participants who were described as potential users and were not identified as belonging to the entities described above.

All involved all the above entities, and we classified the category identified in the reports as success and failure.

\section{Full-Text Analysis}

In addition to categorizing abstracts for success and failure factors of eHealth interventions, we analyzed the full text for the category with the highest frequency of unique articles according to the categorization results. Such analysis was aimed at gathering the data that provide knowledge related to key question 2 .

Articles in which the category with the highest unique article frequency was reported to contribute to the success or failure of the eHealth intervention were eligible for a full-text review. However, in the course of the full-text assessment, we refined the selection according to the exclusion criteria presented in Textbox 3 .

In summary, abstract and full-text reviews were conducted independently by 2 authors (CG and WJ), who extracted data based on the inclusion and exclusion criteria into a structured a Microsoft Excel spreadsheet. The 2 authors analyzed all abstracts a second time to confirm the categorization, identified all relevant factors reported to contribute to the success or failure of eHealth interventions, and noted them in the categorization model. In this manner, every time a new factor was identified, a new category was created. The full-text review was conducted with special attention to the descriptions of how the category with the highest unique article frequency was affecting the success of the eHealth intervention. All disagreements were resolved by consensus discussions.

\section{Results}

The search string identified 903 articles, 7 of which we excluded, as they were duplicates or incomplete. The titles and abstracts of the remaining 896 articles were read by 2 of the authors (CG and WJ) for compliance with the exclusion criteria described in the Methods section, and 221 were included in the study.

Figure 1 presents the literature search and selection process based on the PRISMA guidelines [14].

\section{Key Question 1 (Barriers and Facilitators)}

We defined the categories included in the categorization model based on the information we found in the abstracts. We identified 27 categories, which are summarized and defined in Table 1 [18].

We classified the abstracts of the 221 articles according to the 3 levels described in the Methods section. Multimedia Appendix 1 [19-239] presents the outcomes.

Furthermore, we analyzed the article frequency, as Multimedia Appendix 2 shows.

The narratives on the category (quality of healthcare) most mentioned as contributing to the success of eHealth interventions reported on improved diagnosis [28,72], better communication with the patient $[48,84]$, and supported patient-centered care $[19,48]$. Factors less clinically related were also mentioned, such as the diminishment of the care provision gap for patients [22], and the improvement of patients' clinical management [25]. 
Figure 1. Preferred Reporting Items for Systematic reviews and Meta-Analyses (PRISMA) flowchart of the literature search and article selection.

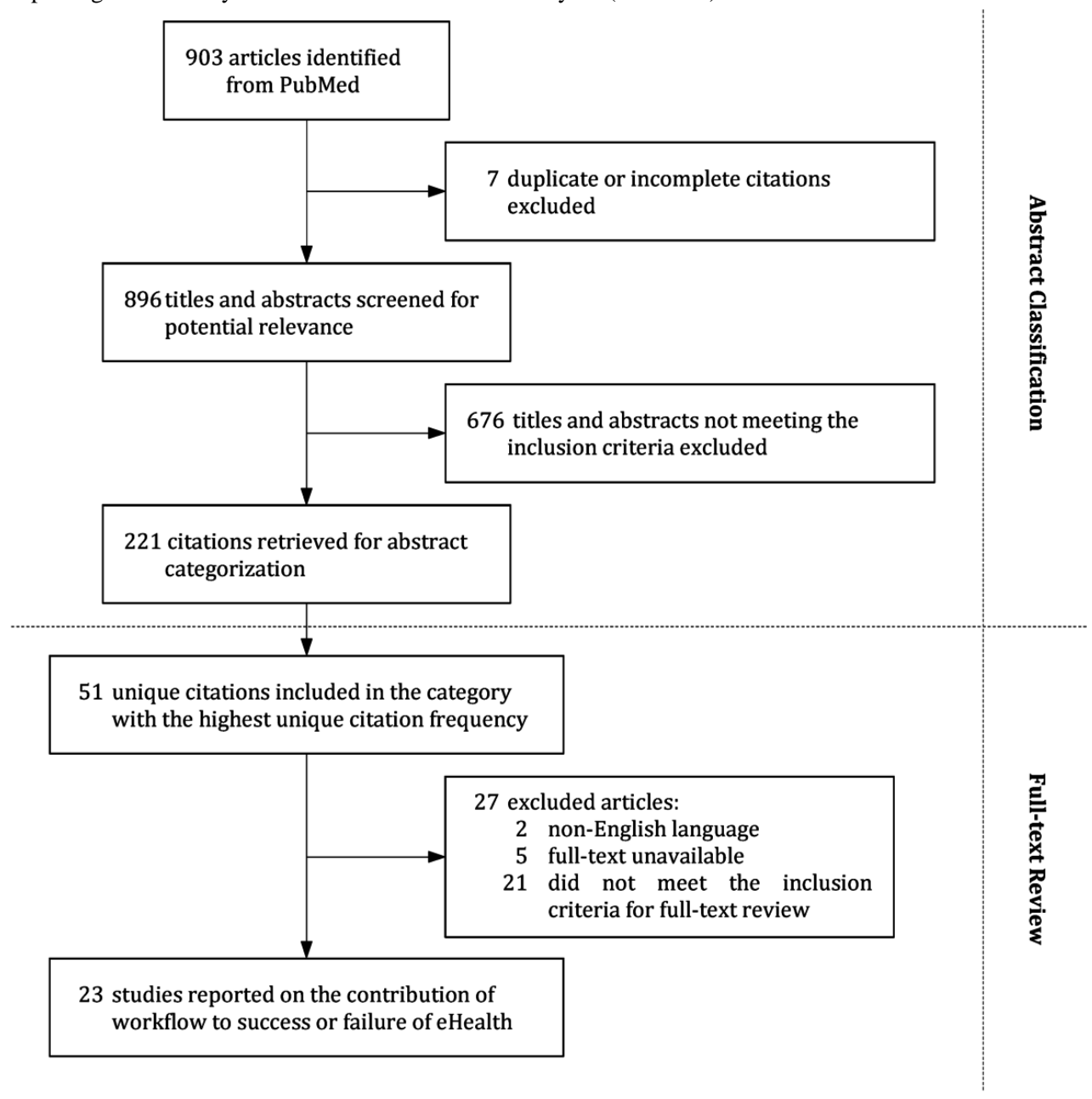

On the other hand, a few articles in the category (costs) most mentioned as contributing to the failure of eHealth interventions established a relationship between the costs and quality of care. As an example, Chan et al [46] pointed out as the main benefit of the eHealth intervention focus of the study that patients in a rural area could be examined by physicians from central hospitals without needing a physical consultation, while at the same time resulting in financial savings. However, the main focus of the articles in this category was on eHealth adoption. Villalba et al [102] identified national investments and funding programs as facilitators in the adoption of 11 eHealth interventions in 8 European countries. O'Toole et al [140], Devriendt et al [45], and Foldy [108] also identified the shortage of financial resources as a common barrier to the adoption and implementation of eHealth. In a similar manner, Ford et al [114] stressed the importance of finding financial mechanisms to support the organizational changes required to adopt eHealth. While acknowledging that a national policy for investment in eHealth interventions is crucial to its adoption, Rozenblum et al [132] argued that financial incentives should be based on patient outcomes that might ensue from the eHealth intervention. DeWorsop et al [129] and Lee and Billings [133] reported on the importance of cost effectiveness to promoting the adoption of eHealth interventions.
To better understand what were, for each entity, the most relevant categories reported to contribute to the success and failure of eHealth interventions, Table 2 summarizes the results from the article frequency analysis. We excluded the society entity from this analysis, as we did not consider the number of articles to be representative.

\section{Key Question 2 (Success/Failure Factors)}

The article frequency analysis, presented in Multimedia Appendix 2, revealed that the most representative category was workflow, with 51 unique articles. We assessed all the unique articles according to the exclusion criteria presented in Textbox 2, which resulted in 23 articles remaining for full-text review (Figure 1).

The full-text analysis of the 23 articles, with special attention to the descriptions of how the workflow category affected the success of the eHealth intervention, identified the following 6 barriers.

Workload increased the amount of work and tasks (or time required to perform them) needed to complete a clinical process, when compared with the workflow established before the eHealth intervention $[19,22,36,69,73,85,87,93,95,98,99,107]$.

Workflow disruption resulted in the inability to complete the work process in a linear and smooth manner $[19,69,73,84,92,106]$. 
Table 1. Categories and their definitions.

\begin{tabular}{ll}
\hline Category & Definition \\
\hline Usability & $\begin{array}{l}\text { Ease of use, learnability (ie, easy for users to learn how to perform basic tasks), and interface intuitiveness } \\
\text { are present. }\end{array}$
\end{tabular}

Adoption

Workflow

Costs

System architecture

Policies

Interoperability

Patient empowerment and self-management

Infrastructure

Leadership

Assessment

Conformity with other healthcare entities

$\mathrm{ICT}^{\mathrm{a}}$ training

Holistic approach

Reliability of connection and technology

Standardization

Culture

ICT vs traditional methods

Privacy and security

Legal

Safety

Access to healthcare

Education

Quality of healthcare

Patient-provider relationship

User involvement

Adherence to treatment
Users acknowledge the use of the eHealth tool.

Workflow is defined by the way people interact with their work, communication pathways, and other people. It should be noted that different professional groups might have different understanding of workflow. As most of the selected abstracts were based on sociological research, this definition excludes the logistics of information flows.

This category includes all articles that reported on money, finances, and value in financial contexts.

This refers to the fundamental organization of a system embodied in its components, their relationships to each other and to the environment, and the principles guiding its design and evolution [18].

The policies category is essentially related to governmental policies and rules. It often involves legal and financial aspects based on subsidies to promote the use of eHealth tools.

This refers to the ability of a system to exchange and make use of information from another system.

These are tools or techniques that give patients control over their own health and access to their health data.

In the context of this study, infrastructure refers to the communication structures required for the operation of the eHealth tool.

This refers to all managerial levels and the decisions made by them.

This category covers considerations of feasibility, efficiency, effectiveness, operational results or other associated outcomes, and the effects of the implementation of eHealth tools.

Conformity refers to the usability of information between healthcare providers in regard to clinical processes and the ability to replicate the eHealth tool implementation in different sites.

This covers user-focused training and support in the use of the eHealth tool.

When the focus is on patient care, this approach implies perceiving the subject of study as a whole person, considering mental and social factors, as opposed to just someone who contracted a disease or disability. When the holistic approach focuses on the organization, this is seen as whole rather than separate entities (ie, departments, wards, and different forms of special care).

This refers to the stability of communications structures during use. The stability and reliability of eHealth tools, both software and hardware related, are also included

Software and hardware conform to standards.

This comprises the culture of an organization, country, region, or population group.

This category considers the comparability between the use of eHealth tools (ICT), and preestablished methods (traditional) (eg, videoconferencing vs face-to-face consultations).

Privacy refers to the confidentiality of personal information, usually relating to personal data stored on computer systems. Security refers to the protection of computer systems against information, communications, and physical damage. In the course of classifying the abstracts, reports on security issues were often related to privacy problems in healthcare settings. Therefore, these 2 categories were combined.

Legal problems relate to legislation issues.

Safety is considered from a clinical perspective.

Access refers to the right of or opportunity for patients to receive, or come in contact with, healthcare organizations or providers.

Education enlightens people about their health (eg, providing information on their disease or disability).

A good quality of healthcare improves the healthcare delivery process and its outcomes, in both an organizational and a clinical context.

healthcare professionals and patients.

This is considered from the human-centered design perspective.

This refers to the patient's compliance with the treatment plan.

${ }^{\mathrm{a}} \mathrm{ICT}$ : information and communication technology. 
Table 2. Categories contributing to the success or failure of eHealth interventions by entity.

\begin{tabular}{llll}
\hline Outcome & Entity & & Health system \\
& Patients & Healthcare professionals & Costs Policies \\
\hline Success & Patient empowerment and self-management & Quality of healthcare & Costs \\
Failure & Privacy and security & Workflow & \\
\hline
\end{tabular}

Alignment with clinical processes was a barrier when the eHealth tool did not integrate with or support the existing clinical process $[38,85]$.

Undefined and changed roles resulted when the responsibility for a workflow task was not the same after the eHealth intervention, or new tasks were included in the workflow and no responsibilities were assigned [22,36,87,95,97,105,106].

Undermined face-to-face communication refers to the impact on personal contact with the patient and other healthcare professionals $[56,72,86,87,91,106]$.

Staff turnover refers to the rotation of healthcare professionals between departments, or short-term contracts, that require new learning or training on the eHealth tool [103].

Workload can be classified as the biggest workflow-related concern, since it was overrepresented in the results, being addressed in 12 of the 23 studies. In these studies, healthcare personnel stressed the increase in the amount of work after the implementation of the eHealth tool. eHealth was described as being both time and resource intensive $[19,22,36,69,73,85,98,99,107]$ and $[19,87,93,95]$ indicated discontent about the amount of self-reported and self-recorded health data provided by the tool for assessment.

The second most mentioned barrier, addressed in 7 studies, was the undefined roles and change of work practice of the parties involved in the workflow. Narratives reported, for instance, that the new role was tangential to their role as healthcare professionals $[22,36,87]$ - for example, coaching patients in the use of the technology, analyzing the self-reported data and subsequently answering the patient's questions [87,95], the need for new competences [97], and unresolved attribution of responsibilities $[105,106]$.

Workflow disruption was significantly present in the studies, reflected in narratives describing eHealth as not being fitted to the existing workflow due to time (eg, data provided to the system a priori, and work tasks having to be performed by others) $[19,73,84,106]$ or space [92] constraints, and breaking of traditions [69].

According to Kapadia et al [83], healthcare personnel report a preference for face-to-face communication over digital long-distance systems. Nielsen and Mathiassen [38] mentioned the loss of contact between personnel as a trigger to the reduction of knowledge sharing and collegial relationships. Less mentioned, but still significant, were statements that eHealth is impersonal and, therefore, undermines face-to-face communication $[56,72,86,87,91,106]$, substantiated by the claim that the foundation of good nursing is physical presence, human touch, and the use of all senses.
Less addressed in the studies, but still significant barriers, were the alignment of the eHealth intervention with the clinical workflow [38,85] and staff turnover [103]. These are related to how supportive and well integrated the tool is in the workflow and the need for constant training of staff, respectively.

In the literature, two general workflows were mentioned. The first was the preestablished workflow, defined as the workflow in an organization, or at a specific organizational level (eg, the cardiology ward in a hospital), before the eHealth intervention. The second was the new workflow, which describes the workflow after the eHealth intervention. Different authors have various ideas about this change.

Some $[38,84,85,92]$ argued that eHealth interventions should be adapted into the preestablished workflow in order to succeed. Others [19,72,73 93,97] advocated that the workflow will change, or is necessary to change, in order for the intervention to be successful.

eHealth interventions in healthcare organizations triggered changes in the workflow $[73,97]$. Such changes were not limited to the directly involved staff, but also had an impact on others within the organization [73]. Therefore, changes in the workflow had the potential to alter the organization both in a negative and in a positive way $[36,38,86,88,103]$. Additionally, a change that was initially a positive development could lead to a rather negative outcome. Such circumstances are reported by Das et al [86], Davis et al [87], and Chung et al [95], where the overabundance of data led to an inability to use the data due to time constraints.

Professional values and personal feelings should also be considered to be barriers to eHealth interventions, as they may come into conflict with the use of technology [36,38]. In these works, feelings of healthcare staff about the technology resulted in negative thoughts and skepticism, resulting in the technology never fully being integrated into the workflow.

\section{Discussion}

\section{General Findings}

There is a reasonable amount of original research exploring the effects of eHealth interventions. However, among the 903 articles we identified, only 221 met the inclusion criteria for this systematic review. The studies were heterogeneous by country, type of eHealth intervention, method of implementation, and reporting perspectives (ie, patient, healthcare professionals, health system, and society). The article frequency analysis presented in Multimedia Appendix 2 did not find a significant discrepancy between the number of reports on failure $(392 / 844,46.5 \%)$ and success $(452 / 844,53.6 \%)$, which encourages definitive conclusions on the key questions that prompted the review. 
While evaluating the 903 articles, we realized that the studies could be grouped into three chronological eras, according to their research focus: (1) up to 1999: in this first era, most of the articles addressed the technology with a focus on aspects such as functionality and infrastructure; (2) 2000-2009: in the second era, the focus shifted from the technology to the organization; in this setting, an organization could be a healthcare organization or a community (local, regional, national, or international); (3) 2010 to the present: the third era focused on individuals, where researchers investigated how people work, often from a bottom-up perspective, compared with a top-down scope on the complete organization.

The first two eras defined in this chronological pattern are supported by Nielsen and Mathiassen [38].

When we applied the three chronological eras to the 221 articles selected for abstract classification, it became clear that the search strategy achieved the desired results in identifying studies with relevant clinical outcomes. This is demonstrated by the fact that most of the articles (168 articles) fell into the third era, and only 3 articles were included in the first era, which had a technological focus.

\section{Key Question 1 (Barriers and Facilitators)}

The category most mentioned as contributing to the success of eHealth interventions was quality of healthcare. This category was also one of the three pillars of care described by Bashshur et al [12] as being the support of successful eHealth interventions. The authors related quality of care to professional performance standards, related the role and contribution of the intervention to clinical practice, and described how this contribution is achieved [12]. This is in line with the narratives found in the articles assigned to this category.

Most of the unique articles in the category quality of healthcare belonged in the third era, with only 9 being in the second era, and none in the first. Belonging in the third era, the focus was on the individual, which could explain the increase in focus on quality of care.

The articles in the quality of healthcare category were evenly distributed among the entities, showing a significant difference between the article frequency as success $(n=55)$ and failure $(n=12)$, and revealing a positive view among the users, thus positioning this category as an evident facilitator of eHealth interventions.

On the other hand, costs is the category most mentioned as contributing to the failure of eHealth interventions. Similar to quality of healthcare, this category is also one of the three pillars of the promises of eHealth proposed by Bashshur et al [12]. In their work, the cost containments pillar focused on cost reductions for patients and providers in a broad sense, supporting a clear definition of how the eHealth intervention would facilitate the provision of care services at a lower cost without loss of quality of care [12]. However, the main focus of the articles in the costs category was on eHealth adoption, and only a few articles established a relation between the costs and quality of care in the manner of Bashshur et al.
The classification of unique articles in the costs category according to the aforementioned eras revealed that most, $80 \%$ (40 articles), fell in the third era. In line with the focus on the individual that characterized this era, we noted that only 13 of the 50 unique articles included results after the eHealth intervention, and that as many as 37 report on expectations, potentials, and other future possibilities. Most of these articles arose from the social sciences and addressed the actors' expectations of eHealth, revealing the general idea that eHealth interventions bring cost reductions along with the implementation. An important aspect of expectations is that they are based on the actors' opinions or wishes, often before the results are clear. However, the actual costs and financial benefits can be measured only after implementation. Since most research was done during the implementation, often at an early stage, this means that data were being collected at a stage when funding was still available and the full impact of the eHealth intervention on the organization was not yet evident. This being said, the costs category certainly presents as a barrier to eHealth interventions.

Looking at the category's article frequency distribution among the entities, costs was mostly mentioned by the health system entity, being, in fact, considered as the most important to both the success and the failure of eHealth interventions. Such lack of a relevant difference between the contribution of costs to success (18 articles) and failure (19 articles) leads to the conclusion that this category is a major concern for the health system. Thus, and since this entity includes organizations and governmental bodies, we conclude that certain financial conditions are required to distribute eHealth services. Hence, we inferred that, to adopt eHealth in their services, it is not important for the health system to attain financial profit, but rather to not have a loss. It is not surprising to see that, along with costs, the category most cited as contributing to that success of eHealth interventions for the health system entity was policies, as the importance of national policy investments and reimbursement rules was so often mentioned in the articles.

However, such perspective on what is most relevant for the success and failure of eHealth interventions is not shared by the other entities. Considering the narratives related to quality of healthcare, described in the Results section, it is not surprising that this category appeared as the most important for the success of eHealth interventions for healthcare professionals. Following the same line of thought, workflow appeared as the most relevant for the failure of eHealth. We discuss the ways in which each of these issues affected the outcome of eHealth interventions below under Key Question 2. However, we can already assert that what these issues have in common is the deprivation of time to provide care services. Conversely, patients considered of most importance that the eHealth interventions support them in managing their own health independently. This is demonstrated in that the most cited category by the patient entity as contributing to the success of eHealth interventions was patient empowerment and self-management. It seems almost too obvious to state that, as patients want to be provided with the means to manage their own health, their most mentioned category as leading to the failure of eHealth was privacy and security. This reveals that, even though patients want to be 
independent and manage their own health remotely, they are aware of the sensitivity of the data that are being shared.

\section{Key Question 2 (Success/Failure Factors)}

Kruse et al [240] examined barriers in eHealth research on a quantitative basis for several consecutive years. In their work, they stated that workflow was one of the most mentioned barriers in literature, which is confirmed by the article frequency analysis presented in Multimedia Appendix 2, where workflow is the category with the most unique articles. This positions this category as being of major concern for the entities.

The claim that eHealth interventions should be fitted to the preestablished workflow in order to succeed $[38,84,85,92]$ was also upheld by Gardner [241] and in the systematic review by Kawamoto et al [242]. In opposition, others [19,72,73,93,97] supported that changes in the workflow are inevitable and necessary for the eHealth intervention to be successful, stressing that the adoption of new eHealth tools within the preestablished workflow creates problems during the implementation process [19]. This is corroborated by the findings in the systematic review by Davis et al [243] and by Bowens et al [244], who also point out that the need to reengineer the workflow to integrate eHealth can be a trigger to improve efficiency, distribution of tasks, patient safety, and the quality of the data collected from the patient. Such disparity of opinions leads to 2 questions. (1) What is the importance of eHealth to workflow? (2) How are the design and the outcomes of eHealth related?

\section{What is the Importance of eHealth to Workflow?}

Healthcare organizations' resistance to change has identified barriers to eHealth interventions [245,246]. Most organizations were not created to accommodate eHealth and, as noted by Appelbaum and Wohl [247], the inability of healthcare organizations to adapt to changes is a barrier to their own sustainability. The resistance to change is also present at the staff level. Pardo del Val and Martinez Fuentes [248] proposed a framework for the sources to resistance to change, among which are the "relation between change values and organizational values," denoting the difference between what is important for the individual and for the organization, and "cynicism," denoting the negative feelings toward the success of the change [249]. This is in line with the narratives on how professional values and personal feelings hinder the use of eHealth [36,38], found in the articles selected for review.

To maximize the likelihood of a successful eHealth intervention, healthcare professionals must acquaint themselves with the tool [250]. Furthermore, there should not be a possibility to fall back on the old workflow $[39,250]$.

\section{How Are the Design and the Outcomes of eHealth Related?}

If eHealth does not meet the expectations or requirements of healthcare personnel, it is possible that the eHealth tool will not be used as anticipated [38]. This is caused by a difference between the prospects, which are often made by management personnel, and the reality of healthcare personnel. In the literature, the technical perspective during the design phase is identified as a significant contributor to the gap between prospect and reality [94,251]. Declerck and Aime [251] used the term technocentrism to classify the importance of technology in the design phase, where other actors, such as healthcare professionals, appear as secondary concerns. In addition, it should be taken into consideration that different professions within healthcare have different needs from eHealth [83], and these needs have to be addressed to make eHealth applications operate successfully in healthcare organizations.

In a veiled manner of recognizing that the technical focus during the design phase was a barrier to eHealth adoption, the technology design mentality shifted to one with a holistic and human focus. There is a widespread perception in human-computer interaction that recognizes that users should be involved in the design in order to create technology that is more relevant, resulting in the wide acceptance of user-centered design and participatory design approaches [252]. Thus, it is legitimate to conclude that the design and the outcomes of eHealth are clearly related, and that user involvement during the design phase is of the most importance for the success eHealth interventions within the domain of workflow.

\section{Conclusions to Key Question 1}

With this systematic review, we identified quality of healthcare as the major facilitator of eHealth interventions and costs as the major barrier.

Within the quality of healthcare category, a positive impact in clinical care appears to be relevant to the adoption of eHealth. The impact is assessed with varied metrics, such as improved diagnosis, clinical management, and patient-centered care. The role of the costs category in the adoption of eHealth seems to be more consensual. Most of the studies included in this category identify the shortage of financial resources as a common barrier to the adoption and implementation of eHealth.

The importance of quality of healthcare in the success of eHealth interventions is shared only by the healthcare professionals entity. The concern of healthcare professionals with care services is also reflected by the workflow category being the most mentioned contributor to the failure of eHealth interventions.

The patient entity revealed their wish of controlling their own health by placing the patient empowerment and self-management character of the intervention as the major contributor to success. However, this wish for control does not come without apprehension, as demonstrated by mentioning the privacy and security category as the major contributor to the failure of eHealth.

The health system entity attributed to 1 category, costs, the same relevance to both success and failure of eHealth interventions. This does not appear as a surprise, as this category mostly relates to financial resources. As these financial resources often originate from governmental sources, it is reasonable that the health system entity mentioned the policies category, along with costs, as a major contributor to the success of eHealth interventions.

\section{Conclusions to Key Question 2}

According to the reviewed literature, workflow was the most relevant factor to the outcome of eHealth interventions across 
all entities. A full-text review identified 6 barriers to the adoption of eHealth related to this category. Most of these barriers were reported by the healthcare professionals entity, and are as follows: (1) workload, (2) workflow disruption, (3) alignment with clinical processes, (4) undefined and changed roles, (5) undermined face-to-face communication, and (6) staff turnover.

\section{Limitations}

Some limitations in this review must be acknowledged. Despite having searched the PubMed database using standard systematic review protocols, we could have searched further databases. This might have limited the results, as the search process may not have captured relevant studies that were not indexed in the PubMed database. However, we considered that the PubMed search alone yielded a representative overview of the field.

Additionally, many studies were based on data that were gathered either before or during the implementation process when the eHealth intervention was not well established in the workplace. As the reports were collected at such an early stage, they might be overshadowed by emotional resistance and fear of change.

\section{Future Research}

In spite of the limitations, this systematic review remains a useful source of information, as it synthesized common challenges in the development of eHealth interventions and in the planning of their implementation. In this regard, considerations for future research include the following:

- Identify potential facilitators and barriers at the earliest possible stage to ensure that full account is taken when defining the development and implementation strategy;

- Determine the impact of eHealth interventions on the quality of care, with particular attention given to improved diagnosis, clinical management, and patient-centered care;

- Evaluate the financial needs and consequences in the short, medium, and long term, to avoid nonadoption due to lack of funding;

- Perform in-depth studies of the workflow(s) that the intervention will support and perceive the clinical processes involved;

- Improve the privacy and security features of eHealth interventions targeted at patients.

\section{Acknowledgments}

CG would like to thank the regional health authority Helse-Nord for funding research projects HST1125-13 and HST1304-16. The authors would also like to thank Gunnar Ellingsen and Gunnar Hartvigsen for their support and insights.

\section{Authors' Contributions}

All authors contributed substantially to the conception and design of the work; approved the final manuscript; and agreed to be accountable for all aspects of the work in ensuring that questions related to the accuracy or integrity of any part of the work are appropriately investigated and resolved. CG and WJ acquired, analyzed, and interpreted the data for the work. CG was the lead writer. WJ and MAJ drafted the manuscript. MAJ analyzed and interpreted the data for the work, and critically revised the manuscript for important intellectual content.

\section{Conflicts of Interest}

None declared.

\section{Multimedia Appendix 1}

Article abstract classification.

[PDF File (Adobe PDF File), 40KB-Multimedia Appendix 1]

\section{Multimedia Appendix 2}

Article frequencies.

\section{[PDF File (Adobe PDF File), 40KB-Multimedia Appendix 2]}

\section{References}

1. World Health Organization. User's guide: the WHO global code of practice on the international recruitment of health personnel. Geneva, Switzerland: WHO; 2011 Jan. URL: http://apps.who.int/iris/bitstream/handle/10665/70525/ WHO HSS HRH HMR 2010.2 eng.pdf;jsessionid=A093F16A3CFED3DCB8C2DE38315DCF2D?sequence=1 [accessed 2018-02-12] [WebCite Cache ID 6yv3vyCys]

2. Parker MG, Thorslund M. Health trends in the elderly population: getting better and getting worse. Gerontologist 2007 Apr;47(2):150-158. [Medline: 17440120$]$

3. Ward BW, Schiller JS. Prevalence of multiple chronic conditions among US adults: estimates from the National Health Interview Survey, 2010. Prev Chronic Dis 2013 Apr 25;10:E65 [FREE Full text] [doi: 10.5888/pcd10.120203] [Medline: 23618545] 
4. Christensen K, Doblhammer G, Rau R, Vaupel JW. Ageing populations: the challenges ahead. Lancet 2009 Oct 3;374(9696):1196-1208 [FREE Full text] [doi: 10.1016/S0140-6736(09)61460-4] [Medline: 19801098]

5. Ågren G, Berensson K. Healthy Ageing -- A Challenge for Europe. Stockholm, Sweden: The Swedish National Institute of Public Health; 2006.

6. Goldberg HS, Morales A, Gottlieb L, Meador L, Safran C. Reinventing patient-centered computing for the twenty-first century. Stud Health Technol Inform 2001;84(Pt 2):1455-1458. [Medline: 11604967]

7. Hjelm NM. Benefits and drawbacks of telemedicine. J Telemed Telecare 2005 Jan;11(2):60-70. [doi: 10.1258/1357633053499886] [Medline: 15829049 ]

8. Tanriverdi H, Iacono C. Knowledge barriers to diffusion of telemedicine. In: Proceedings of the International Conference on Information systems. Atlanta, GA: Association for Information Systems; 1998 Dec Presented at: ICIS; Dec 13-16, 1998; Helsinki, Finland p. 13-16 URL: https://dl.acm.org/citation.cfm?id=353057 [doi: 10.1145/353053.353057]

9. Jung M, Berthon P. Fulfilling the promise: a model for delivering successful online health care. J Med Marketing 2009 Jul;9(3):243-254. [doi: 10.1057/jmm.2009.26]

10. Shortliffe EH. Strategic action in health information technology: why the obvious has taken so long. Health Aff (Millwood)

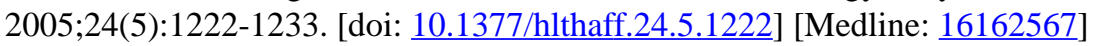

11. Berg M. Patient care information systems and health care work: a sociotechnical approach. Int J Med Inform 1999 Aug;55(2):87-101. [Medline: 10530825]

12. Bashshur RL, Shannon G, Krupinski EA, Grigsby J. Sustaining and realizing the promise of telemedicine. Telemed J E Health 2013 May;19(5):339-345 [FREE Full text] [doi: 10.1089/tmj.2012.0282] [Medline: 23289907]

13. Higgins J, Green S. Cochrane Handbook for Systematic Reviews of Interventions. West Sussex, UK: John Wiley \& Sons; 2011.

14. Moher D, Liberati A, Tetzlaff J, Altman DG. Preferred reporting items for systematic reviews and meta-analyses: the PRISMA statement. BMJ 2009;339:b2535 [FREE Full text] [Medline: 19622551]

15. Schardt C, Adams MB, Owens T, Keitz S, Fontelo P. Utilization of the PICO framework to improve searching PubMed for clinical questions. BMC Med Inform Decis Mak 2007;7:16 [FREE Full text] [doi: 10.1186/1472-6947-7-16] [Medline: 17573961]

16. Hsieh H, Shannon SE. Three approaches to qualitative content analysis. Qual Health Res 2005 Nov;15(9):1277-1288. [doi: 10.1177/1049732305276687] [Medline: 16204405]

17. Graneheim UH, Lundman B. Qualitative content analysis in nursing research: concepts, procedures and measures to achieve trustworthiness. Nurse Educ Today 2004 Feb;24(2):105-112. [doi: 10.1016/j.nedt.2003.10.001] [Medline: 14769454]

18. ISO/IEC/IEEE. Systems software engineering -- architecture description. In: ISO/IEC/IEEE 42010:2011(E) (Revision of ISO/IEC 42010:2007 and IEEE Std 1471-2000). New York, NY: IEEE; Dec 01, 2011.

19. Steele GC, Gill A, Khan AI, Hans PK, Kuluski K, Cott C. The electronic patient reported outcome tool: testing usability and feasibility of a mobile app and portal to support care for patients with complex chronic disease and disability in primary care settings. JMIR Mhealth Uhealth 2016 Jun 02;4(2):e58 [FREE Full text] [doi: 10.2196/mhealth.5331] [Medline: 27256035]

20. Duman-Lubberding S, van Uden-Kraan CF, Jansen F, Witte BI, van der Velden LA, Lacko M, et al. Feasibility of an eHealth application "OncoKompas" to improve personalized survivorship cancer care. Support Care Cancer 2016 May;24(5):2163-2171 [FREE Full text] [doi: 10.1007/s00520-015-3004-2] [Medline: 26563178]

21. Hoque MR. An empirical study of mHealth adoption in a developing country: the moderating effect of gender concern. BMC Med Inform Decis Mak 2016 Dec 03;16:51 [FREE Full text] [doi: 10.1186/s12911-016-0289-0] [Medline: 27142844]

22. Hunting G, Shahid N, Sahakyan Y, Fan I, Moneypenny CR, Stanimirovic A, et al. A multi-level qualitative analysis of Telehomecare in Ontario: challenges and opportunities. BMC Health Serv Res 2015 Dec 09;15:544 [FREE Full text] [doi: 10.1186/s12913-015-1196-2] [Medline: 26645639]

23. Jiménez-Fernández S, de Toledo P, del Pozo F. Usability and interoperability in wireless sensor networks for patient telemonitoring in chronic disease management. IEEE transactions on bio-medical engineering. IEEE Trans Biomed Eng 2013 Dec;60(12):3331-3339. [doi: 10.1109/TBME.2013.2280967] [Medline: 24021636]

24. Manafò E, Wong S. Promoting eHealth literacy in older adults: key informant perspectives. Can J Diet Pract Res 2013;74(1):37-41. [doi: 10.3148/74.1.2013.37] [Medline: 23449214]

25. Marzegalli M, Lunati M, Landolina M, Perego GB, Ricci RP, Guenzati G, et al. Remote monitoring of CRT-ICD: the multicenter Italian CareLink evaluation--ease of use, acceptance, and organizational implications. Pacing Clin Electrophysiol 2008 Oct;31(10):1259-1264. [doi: 10.1111/j.1540-8159.2008.01175.x] [Medline: 18811805]

26. Nikander K, Denyer J, Dodd M, Dyche T, Webb K, Weller P, et al. The Adaptive Aerosol Delivery system in a telehealth setting: patient acceptance, performance and feasibility. J Aerosol Med Pulm Drug Deliv 2010 Apr;23 Suppl 1:S21-S27 [FREE Full text] [doi: 10.1089/jamp.2009.0770] [Medline: 20373906]

27. Nitsch M, Dimopoulos CN, Flaschberger E, Saffran K, Kruger JF, Garlock L, et al. A guided online and mobile self-help program for individuals with eating disorders: an iterative engagement and usability study. J Med Internet Res 2016 Jan 11;18(1):e7 [FREE Full text] [doi: 10.2196/jmir.4972] [Medline: 26753539] 
28. Palmier-Claus JE, Rogers A, Ainsworth J, Machin M, Barrowclough C, Laverty L, et al. Integrating mobile-phone based assessment for psychosis into people's everyday lives and clinical care: a qualitative study. BMC Psychiatry 2013;13:34 [FREE Full text] [doi: 10.1186/1471-244X-13-34] [Medline: 23343329]

29. Pelayo S, Ong M. Human factors and ergonomics in the design of health information technology: trends and progress in 2014. Yearb Med Inform 2015 Aug 13;10(1):75-78 [FREE Full text] [doi: 10.15265/IY-2015-033] [Medline: 26293852]

30. Prescher S, Deckwart O, Winkler S, Koehler K, Honold M, Koehler F. Telemedical care: feasibility and perception of the patients and physicians: a survey-based acceptance analysis of the Telemedical Interventional Monitoring in Heart Failure (TIM-HF) trial. Eur J Prev Cardiol 2013 Jun;20(2 Suppl):18-24. [doi: 10.1177/2047487313487483e] [Medline: 23702987]

31. Robben SHM, Perry M, Huisjes M, van Nieuwenhuijzen L, Schers HJ, van Weel C, et al. Implementation of an innovative web-based conference table for community-dwelling frail older people, their informal caregivers and professionals: a process evaluation. BMC Health Serv Res 2012 Aug 15;12:251 [FREE Full text] [doi: 10.1186/1472-6963-12-251] [Medline: 22894654]

32. Greenhalgh T, Hinder S, Stramer K, Bratan T, Russell J. Adoption, non-adoption, and abandonment of a personal electronic health record: case study of HealthSpace. BMJ 2010;341:c5814 [FREE Full text] [Medline: 21081595]

33. Ehrler F, Lovis C. Supporting elderly homecare with smartwatches: advantages and drawbacks. Stud Health Technol Inform 2014;205:667-671. [Medline: 25160270]

34. Kreps GL, Neuhauser L. New directions in eHealth communication: opportunities and challenges. Patient Educ Couns 2010 Mar;78(3):329-336. [doi: 10.1016/j.pec.2010.01.013] [Medline: 20202779]

35. Radhakrishnan K, Xie B, Jacelon CS. Unsustainable home telehealth: a Texas qualitative study. Gerontologist 2016 Oct;56(5):830-840. [doi: 10.1093/geront/gnv050] [Medline: 26035878]

36. Sølling IK, Carøe P, Mathiesen KS. Development and implementation of IT require focus on user participation, acceptance and workflow. Stud Health Technol Inform 2014;201:219-226. [Medline: 24943547]

37. Zhang X, Yu P, Yan J. Patients' adoption of the e-appointment scheduling service: A case study in primary healthcare. Stud Health Technol Inform 2014;204:176-181. [Medline: 25087546]

38. Nielsen JA, Mathiassen L. Interpretive flexibility in mobile health: lessons from a government-sponsored home care program. J Med Internet Res 2013 Oct 30;15(10):e236 [FREE Full text] [doi: 10.2196/jmir.2816] [Medline: 24172852]

39. Abbott KC, Mann S, DeWitt D, Sales LY, Kennedy S, Poropatich RK. Physician-to-physician consultation via electronic mail: the Walter Reed Army Medical Center Ask a Doc system. Mil Med 2002 Mar;167(3):200-204. [Medline: 11901566]

40. Eason K, Waterson P. The implications of e-health system delivery strategies for integrated healthcare: lessons from England. Int J Med Inform 2013 May;82(5):e96-e106. [doi: 10.1016/j.ijmedinf.2012.11.004] [Medline: 23266062]

41. Fonda SJ, Paulsen CA, Perkins J, Kedziora RJ, Rodbard D, Bursell SE. Usability test of an internet-based informatics tool for diabetes care providers: the comprehensive diabetes management program. Diabetes Technol Ther 2008 Feb;10(1):16-24. [doi: 10.1089/dia.2007.0252] [Medline: 18275359]

42. Landman A, Emani S, Carlile N, Rosenthal DI, Semakov S, Pallin DJ, et al. A mobile app for securely capturing and transferring clinical images to the electronic health record: description and preliminary usability study. JMIR Mhealth Uhealth 2015;3(1):e1 [FREE Full text] [doi: 10.2196/mhealth.3481] [Medline: 25565678]

43. Lodhia V, Karanja S, Lees S, Bastawrous A. Acceptability, usability, and views on deployment of Peek, a mobile phone mHealth intervention for eye care in Kenya: qualitative study. JMIR Mhealth Uhealth 2016 May 09;4(2):e30 [FREE Full text] [doi: 10.2196/mhealth.4746] [Medline: 27160779]

44. Sinclair C, Holloway K, Riley G, Auret K. Online mental health resources in rural Australia: clinician perceptions of acceptability. J Med Internet Res 2013;15(9):e193 [FREE Full text] [doi: 10.2196/jmir.2772] [Medline: 24007949]

45. Devriendt E, Wellens NIH, Flamaing J, Declercq A, Moons P, Boonen S, et al. The interRAI Acute Care instrument incorporated in an eHealth system for standardized and web-based geriatric assessment: strengths, weaknesses, opportunities and threats in the acute hospital setting. BMC Geriatr 2013 Sep 05;13:90 [FREE Full text] [doi: 10.1186/1471-2318-13-90] [Medline: 24007312]

46. Chan FY, Soong B, Watson D, Whitehall J. Realtime fetal ultrasound by telemedicine in Queensland. A successful venture? J Telemed Telecare 2001;7 Suppl 2:7-11. [doi: 10.1258/1357633011937290] [Medline: 11747644]

47. Baldwin JL, Singh H, Sittig DF, Giardina TD. Patient portals and health apps: pitfalls, promises, and what one might learn from the other. Healthc (Amst) 2017 Sep 3;5(3):81-85 [FREE Full text] [doi: 10.1016/j.hjdsi.2016.08.004] [Medline: 27720139]

48. George SM, Hamilton A, Baker R. Pre-experience perceptions about telemedicine among African Americans and Latinos in South Central Los Angeles. Telemed J E Health 2009;15(6):525-530 [FREE Full text] [doi: 10.1089/tmj.2008.0152] [Medline: 19566397]

49. Steele GC, Miller D, Kuluski K, Cott C. Tying eHealth tools to patient needs: exploring the use of ehealth for community-dwelling patients with complex chronic disease and disability. JMIR Res Protoc 2014;3(4):e67 [FREE Full text] [doi: 10.2196/resprot.3500] [Medline: 25428028]

50. Islam SMS, Tabassum R. Implementation of information and communication technologies for health in Bangladesh. Bull World Health Organ 2015 Nov 01;93(11):806-809 [FREE Full text] [doi: 10.2471/BLT.15.153684] [Medline: 26549909] 
51. Darkins A. Program management of telemental health care services. J Geriatr Psychiatry Neurol 2001;14(2):80-87. [doi: 10.1177/089198870101400207] [Medline: 11419572]

52. El-Mahalli AA, El-Khafif SH, Al-Qahtani MF. Successes and challenges in the implementation and application of telemedicine in the eastern province of Saudi Arabia. Perspect Health Inf Manag 2012;9:1-27 [FREE Full text] [Medline: 23209455]

53. Greenberg A, Kramer S, Welch V, O'Sullivan E, Hall S. Cancer Care Ontario's computerized physician order entry system: a province-wide patient safety innovation. Healthc Q 2006;9 Spec No:108-113 [FREE Full text] [Medline: 17087178]

54. Taylor J, Coates E, Brewster L, Mountain G, Wessels B, Hawley MS. Examining the use of telehealth in community nursing: identifying the factors affecting frontline staff acceptance and telehealth adoption. J Adv Nurs 2015 Feb;71(2):326-337. [doi: 10.1111/jan.12480] [Medline: 25069605]

55. Al-Qirim N. Realizing telemedicine advantages at the national level: cases from the United Arab Emirates. Telemed J E Health 2007 Oct;13(5):545-555. [doi: 10.1089/tmj.2006.0087] [Medline: 17999616]

56. King G, Richards H, Godden D. Adoption of telemedicine in Scottish remote and rural general practices: a qualitative study. J Telemed Telecare 2007;13(8):382-386. [doi: 10.1258/135763307783064430] [Medline: 18078547]

57. Ndetei DM, Jenkins R. The implementation of mental health information systems in developing countries: challenges and opportunities. Epidemiol Psichiatr Soc 2009;18(1):12-16. [Medline: 19378693]

58. Ruas SSM, Assunção AÁ. Teleconsultations by primary care physicians of Belo Horizonte: challenges in the diffusion of innovation. Telemed J E Health 2013 May;19(5):409-414. [doi: 10.1089/tmj.2012.0095] [Medline: 23600411]

59. Hung MC, Jen WY. The adoption of mobile health management services: an empirical study. J Med Syst 2012 Jun;36(3):1381-1388. [doi: 10.1007/s10916-010-9600-2] [Medline: 20878452]

60. Choi W, Park M, Hong E, Kim S, Ahn R, Hong J, et al. Early experiences with mobile electronic health records application in a tertiary hospital in Korea. Healthc Inform Res 2015 Oct;21(4):292-298 [FREE Full text] [doi: 10.4258/hir.2015.21.4.292] [Medline: 26618036]

61. Lin CH, Lin IC, Roan JS, Yeh JS. Critical factors influencing hospitals' adoption of HL7 version 2 standards: an empirical investigation. J Med Syst 2012 Jun;36(3):1183-1192. [doi: 10.1007/s10916-010-9580-2] [Medline: 20827568]

62. Mergel I. The long way from government open data to mobile health apps: overcoming institutional barriers in the US Federal Government. JMIR Mhealth Uhealth 2014;2(4):e58 [FREE Full text] [doi: 10.2196/mhealth.3694] [Medline: 25537314]

63. Schnall R, Odlum M, Gordon P, Bakken S. Barriers to implementation of a Continuity of Care Record (CCR) in HIV/AIDS care. Stud Health Technol Inform 2009;146:248-252 [FREE Full text] [Medline: 19592843]

64. Bull TP, Dewar AR, Malvey DM, Szalma JL. Considerations for the telehealth systems of tomorrow: an analysis of student perceptions of telehealth technologies. JMIR Med Educ 2016 Jul 08;2(2):e11 [FREE Full text] [doi: 10.2196/mededu.5392] [Medline: 27731865]

65. Davis TL, DiClemente R, Prietula M. Taking mHealth forward: examining the core characteristics. JMIR Mhealth Uhealth 2016 Aug 10;4(3):e97 [FREE Full text] [doi: 10.2196/mhealth.5659] [Medline: 27511612]

66. Fico G, Arredondo MT. Use of an holistic approach for effective adoption of user-centred-design techniques in diabetes disease management: experiences in user need elicitation. Conf Proc IEEE Eng Med Biol Soc 2015;2015:2139-2142. [doi: 10.1109/EMBC.2015.7318812] [Medline: 26736712]

67. Finocchario-Kessler S, Odera I, Okoth V, Bawcom C, Gautney B, Khamadi S, et al. Lessons learned from implementing the HIV infant tracking system (HITSystem): a web-based intervention to improve early infant diagnosis in Kenya. Healthc (Amst) 2015 Dec;3(4):190-195 [FREE Full text] [doi: 10.1016/j.hjdsi.2015.07.004] [Medline: 26699342]

68. Follen M, Castaneda R, Mikelson M, Johnson D, Wilson A, Higuchi K. Implementing health information technology to improve the process of health care delivery: a case study. Dis Manag 2007 Aug;10(4):208-215. [doi: 10.1089/dis.2007.104706] [Medline: 17718659 ]

69. Janols R, Lind T, Göransson B, Sandblad B. Evaluation of user adoption during three module deployments of region-wide electronic patient record systems. Int J Med Inform 2014 Jun;83(6):438-449. [doi: 10.1016/j.ijmedinf.2014.02.003] [Medline: 24630924]

70. Ray KN, Felmet KA, Hamilton MF, Kuza CC, Saladino RA, Schultz BR, et al. Clinician attitudes toward adoption of pediatric emergency telemedicine in rural hospitals. Pediatr Emerg Care 2017 Apr 16;33(4):250--2257. [doi: 10.1097/PEC.0000000000000583] [Medline: 26785087]

71. Saranummi N, Beuscart R, Black N, Maglaveras N, Strano C, Karavidopoulou Y. Adoption space and the idea-to-market process of health technologies. Stud Health Technol Inform 2016;224:9-14. [Medline: 27225546]

72. Praveen D, Patel A, Raghu A, Clifford GD, Maulik PK, Mohammad AA, et al. SMARTHealth India: development and field evaluation of a mobile clinical decision support system for cardiovascular diseases in rural India. JMIR Mhealth Uhealth 2014 Dec 08;2(4):e54 [FREE Full text] [doi: 10.2196/mhealth.3568] [Medline: 25487047]

73. Aas IH. A qualitative study of the organizational consequences of telemedicine. J Telemed Telecare 2001;7(1):18-26. [doi: $\underline{10.1258 / 1357633011936093]}$ [Medline: 11265934] 
74. Ancker JS, Witteman HO, Hafeez B, Provencher T, van de Graaf M, Wei E. "You get reminded you're a sick person": personal data tracking and patients with multiple chronic conditions. J Med Internet Res 2015;17(8):e202 [FREE Full text] [doi: 10.2196/jmir.4209] [Medline: 26290186]

75. Bradford NK, Caffery LJ, Smith AC. Awareness, experiences and perceptions of telehealth in a rural Queensland community. BMC Health Serv Res 2015 Sep 28;15:427 [FREE Full text] [doi: 10.1186/s12913-015-1094-7] [Medline: 26416464]

76. Damanpour S, Srivastava D, Nijhawan RI. Self-acquired patient images: the promises and the pitfalls. Semin Cutan Med Surg 2016 Mar;35(1):13-17. [doi: 10.12788/j.sder.2016.013] [Medline: 26963112]

77. De Asmundis C, Ricciardi D, Namdar M, Pappaert G, Rodríguez-Mañero M, Wauters K, et al. ICD function and dysfunction in patients with arrhythmogenic cardiac diseases: the role of home monitoring. Acta Cardiol 2013 Aug;68(4):387-394. [doi: 10.2143/AC.68.4.2988892] [Medline: 24187765]

78. Farzanfar R, Finkelstein J, Friedman RH. Testing the usability of two automated home-based patient-management systems. J Med Syst 2004 Apr;28(2):143-153. [Medline: 15195845]

79. Gabrielian S, Yuan A, Andersen RM, McGuire J, Rubenstein L, Sapir N, et al. Chronic disease management for recently homeless veterans: a clinical practice improvement program to apply home telehealth technology to a vulnerable population. Med Care 2013 Mar;51(3 Suppl 1):S44-S51 [FREE Full text] [doi: 10.1097/MLR.0b013e31827808f6] [Medline: 23407011]

80. Holmström I. Decision aid software programs in telenursing: not used as intended? Experiences of Swedish telenurses. Nurs Health Sci 2007 Mar;9(1):23-28. [doi: 10.1111/j.1442-2018.2007.00299.x] [Medline: 17300541]

81. Cook EJ, Randhawa G, Sharp C, Ali N, Guppy A, Barton G, et al. Exploring the factors that influence the decision to adopt and engage with an integrated assistive telehealth and telecare service in Cambridgeshire, UK: a nested qualitative study of patient 'users' and 'non-users'. BMC Health Serv Res 2016 Apr 19;16:137 [FREE Full text] [doi: 10.1186/s12913-016-1379-5] [Medline: 27095102]

82. Donkin L, Glozier N. Motivators and motivations to persist with online psychological interventions: a qualitative study of treatment completers. J Med Internet Res 2012;14(3):e91 [FREE Full text] [doi: 10.2196/jmir.2100] [Medline: 22743581]

83. Kapadia V, Ariani A, Li J, Ray PK. Emerging ICT implementation issues in aged care. Int J Med Inform 2015 Nov;84(11):892-900. [doi: 10.1016/j.ijmedinf.2015.07.002] [Medline: 26250987]

84. Hao WR, Hsu YH, Chen KC, Li HC, Iqbal U, Nguyen PA, et al. LabPush: a pilot study of providing remote clinics with laboratory results via short message service (SMS) in Swaziland, Africa - a qualitative study. Comput Methods Programs Biomed 2015 Jan;118(1):77-83. [doi: 10.1016/j.cmpb.2014.10.005] [Medline: 25453385]

85. Nazi KM. The personal health record paradox: health care professionals' perspectives and the information ecology of personal health record systems in organizational and clinical settings. J Med Internet Res 2013 Apr 04;15(4):e70 [FREE Full text] [doi: 10.2196/jmir.2443] [Medline: 23557596]

86. Das A, Faxvaag A, Svanæs D. The impact of an eHealth portal on health care professionals' interaction with patients: qualitative study. J Med Internet Res 2015 Nov 24;17(11):e267 [FREE Full text] [doi: 10.2196/jmir.4950] [Medline: 26601678]

87. Davis MM, Currey JM, Howk S, DeSordi MR, Boise L, Fagnan LJ, et al. A qualitative study of rural primary care clinician views on remote monitoring technologies. J Rural Health 2014;30(1):69-78 [FREE Full text] [doi: 10.1111/jrh.12027] [Medline: 24383486]

88. Koru G, Alhuwail D, Topaz M, Norcio AF, Mills ME. Investigating the challenges and opportunities in home care to facilitate effective information technology adoption. J Am Med Dir Assoc 2016 Jan;17(1):53-58. [doi:

10.1016/j.jamda.2015.10.008] [Medline: 26612483]

89. Loscertales FR, Rubió FS. [Facilitators in the implantation of telemedicine services. Perspective of professionals involved in its design and implementation]. An Sist Sanit Navar 2011;34(2):235-244 [FREE Full text] [Medline: 21904405]

90. Menachemi N, Brooks RG, Schwalenstocker E, Simpson L. Use of health information technology by children's hospitals in the United States. Pediatrics 2009 Jan;123 Suppl 2:S80-S84. [doi: 10.1542/peds.2008-1755F] [Medline: 19088234]

91. Randell R, Backhouse MR, Nelson EA. Videoconferencing for site initiations in clinical studies: mixed methods evaluation of usability, acceptability, and impact on recruitment. Inform Health Soc Care 2016 Dec;41(4):362-372. [doi: 10.3109/17538157.2015.1064424] [Medline: 26694583]

92. Rossos PG, St-Cyr O, Purdy B, Toenjes C, Masino C, Chmelnitsky D. Hype, harmony and human factors: applying user-centered design to achieve sustainable telehealth program adoption and growth. Stud Health Technol Inform 2015;209:121-127. [Medline: 25980714]

93. MacNeill V, Sanders C, Fitzpatrick R, Hendy J, Barlow J, Knapp M, et al. Experiences of front-line health professionals in the delivery of telehealth: a qualitative study. Br J Gen Pract 2014 Jul;64(624):e401-e407 [FREE Full text] [doi: 10.3399/bjgp14X680485] [Medline: 24982492]

94. Biggs K, Lowe P, Walsh J, Lagios K. Audit of a sexual health website email link for general practitioners. Int J STD AIDS 2010 Jan;21(1):60-62. [doi: 10.1258/ijsa.2009.009192] [Medline: 20029066]

95. Chung C, Cook J, Bales E, Zia J, Munson SA. More than telemonitoring: health provider use and nonuse of life-log data in irritable bowel syndrome and weight management. J Med Internet Res 2015;17(8):e203 [FREE Full text] [doi:

10.2196/jmir.4364] [Medline: 26297627] 
96. de Grood C, Eso K, Santana MJ. Physicians' experience adopting the electronic transfer of care communication tool: barriers and opportunities. J Multidiscip Healthc 2015;8:21-31 [FREE Full text] [doi: 10.2147/JMDH.S72953] [Medline: 25609977]

97. Lamothe L, Fortin J, Labbé F, Gagnon M, Messikh D. Impacts of telehomecare on patients, providers, and organizations. Telemed J E Health 2006 Jun;12(3):363-369. [doi: 10.1089/tmj.2006.12.363] [Medline: 16796505]

98. McCullough JM, Zimmerman FJ, Bell DS, Rodriguez HP. Electronic health information exchange in underserved settings: examining initiatives in small physician practices \& community health centers. BMC Health Serv Res 2014;14:415 [FREE Full text] [doi: 10.1186/1472-6963-14-415] [Medline: 25240718]

99. Schooley B, Walczak S, Hikmet N, Patel N. Impacts of mobile tablet computing on provider productivity, communications, and the process of care. Int J Med Inform 2016 Apr;88:62-70. [doi: 10.1016/j.ijmedinf.2016.01.010] [Medline: 26878764]

100. Singh R, Mathiassen L, Stachura ME, Astapova EV. Sustainable rural telehealth innovation: a public health case study. Health Serv Res 2010 Aug;45(4):985-1004 [FREE Full text] [doi: 10.1111/j.1475-6773.2010.01116.x] [Medline: 20459449]

101. Smith KL, Kerr DA, Fenner AA, Straker LM. Adolescents just do not know what they want: a qualitative study to describe obese adolescents' experiences of text messaging to support behavior change maintenance post intervention. J Med Internet Res 2014;16(4):e103 [FREE Full text] [doi: 10.2196/jmir.3113] [Medline: 24713407]

102. Villalba E, Casas I, Abadie F, Lluch M. Integrated personal health and care services deployment: experiences in eight European countries. Int J Med Inform 2013 Jul;82(7):626-635. [doi: 10.1016/j.ijmedinf.2013.03.002] [Medline: 23587432]

103. Barrett M, Larson A, Carville K, Ellis I. Challenges faced in implementation of a telehealth enabled chronic wound care system. Rural Remote Health 2009;9(3):1154 [FREE Full text] [Medline: 19705955]

104. Roig F, Saigí F. Barriers to the normalization of telemedicine in a healthcare system model based on purchasing of healthcare services using providers' contracts. Gac Sanit 2011;25(5):397-402 [FREE Full text] [doi: 10.1016/j.gaceta.2011.01.004] [Medline: 21719160]

105. Sørensen T, Dyb K, Rygh E, Salvesen R, Thomassen L. A qualitative description of telemedicine for acute stroke care in Norway: technology is not the issue. BMC Health Serv Res 2014 Dec 19;14:643 [FREE Full text] [doi: 10.1186/s12913-014-0643-9] [Medline: 25523241]

106. Embi PJ, Weir C, Efthimiadis EN, Thielke SM, Hedeen AN, Hammond KW. Computerized provider documentation: findings and implications of a multisite study of clinicians and administrators. J Am Med Inform Assoc 2013;20(4):718-726 [FREE Full text] [doi: 10.1136/amiajnl-2012-000946] [Medline: 23355462]

107. Fairbrother P, Ure J, Hanley J, McCloughan L, Denvir M, Sheikh A, et al. Telemonitoring for chronic heart failure: the views of patients and healthcare professionals - a qualitative study. J Clin Nurs 2014 Jan;23(1-2):132-144. [doi: 10.1111/jocn.12137] [Medline: 23451899]

108. Foldy S. Inventory of electronic health information exchange in Wisconsin, 2006. WMJ 2007 May;106(3):120-125 [FREE Full text] [Medline: $\underline{17642349}$ ]

109. Levin D. MHealth: promise and pitfalls. Front Health Serv Manage 2012;29(2):33-9; discussion 40. [Medline: 23330301]

110. Park H, Chon Y, Lee J, Choi I, Yoon KH. Service design attributes affecting diabetic patient preferences of telemedicine in South Korea. Telemed J E Health 2011;17(6):442-451 [FREE Full text] [doi: 10.1089/tmj.2010.0201] [Medline: 21631382]

111. Fuji KT, Abbott AA, Galt KA. A qualitative study of how patients with type 2 diabetes use an electronic stand-alone personal health record. Telemed J E Health 2015 Apr;21(4):296-300. [doi: 10.1089/tmj.2014.0084] [Medline: 25614996]

112. Goldberg EM, Levy PD. New approaches to evaluating and monitoring blood pressure. Curr Hypertens Rep 2016 Dec;18(6):49. [doi: 10.1007/s11906-016-0650-9] [Medline: 27137524]

113. Glick G, Druss B, Pina J, Lally C, Conde M. Use of mobile technology in a community mental health setting. J Telemed Telecare 2016 Oct;22(7):430-435. [doi: 10.1177/1357633X15613236] [Medline: 26519378]

114. Ford JH, Alagoz E, Dinauer S, Johnson KA, Pe-Romashko K, Gustafson DH. Successful organizational strategies to sustain use of A-CHESS: a mobile intervention for individuals with alcohol use disorders. J Med Internet Res 2015 Aug 18;17(8):e201 [FREE Full text] [doi: 10.2196/jmir.3965] [Medline: 26286257]

115. Jamoom EW, Patel V, Furukawa MF, King J. EHR adopters vs. non-adopters: impacts of, barriers to, and federal initiatives for EHR adoption. Healthc (Amst) 2014 Mar;2(1):33-39 [FREE Full text] [doi: 10.1016/j.hjdsi.2013.12.004] [Medline: 26250087]

116. Minichiello V, Rahman S, Dune T, Scott J, Dowsett G. E-health: potential benefits and challenges in providing and accessing sexual health services. BMC Public Health 2013;13:790 [FREE Full text] [doi: 10.1186/1471-2458-13-790] [Medline: 23987137]

117. Cason J, Behl D, Ringwalt S. Overview of states' use of telehealth for the delivery of early intervention (IDEA Part C) services. Int J Telerehabil 2012;4(2):39-46 [FREE Full text] [doi: 10.5195/IJT.2012.6105] [Medline: 25945202]

118. Lee SI, Park H, Kim JW, Hwang H, Cho EY, Kim Y, et al. Physicians' perceptions and use of a health information exchange: a pilot program in South Korea. Telemed J E Health 2012 Oct;18(8):604-612 [FREE Full text] [doi: 10.1089/tmj.2011.0261] [Medline: 22352898]

119. Leung GM, Yu PL, Wong IO, Johnston JM, Tin KY. Incentives and barriers that influence clinical computerization in Hong Kong: a population-based physician survey. J Am Med Inform Assoc 2003;10(2):201-212 [FREE Full text] [Medline: 12595409] 
120. Mattocks K, Lalime K, Tate JP, Giannotti TE, Carr K, Carrabba A, et al. The state of physician office-based health information technology in Connecticut: current use, barriers and future plans. Conn Med 2007 Jan;71(1):27-31. [Medline: 17288104]

121. May CR, Finch TL, Cornford J, Exley C, Gately C, Kirk S, et al. Integrating telecare for chronic disease management in the community: what needs to be done? BMC Health Serv Res 2011;11:131 [FREE Full text] [doi: 10.1186/1472-6963-11-131] [Medline: 21619596]

122. Molfenter T, Boyle M, Holloway D, Zwick J. Trends in telemedicine use in addiction treatment. Addict Sci Clin Pract 2015 May 28;10:14 [FREE Full text] [doi: 10.1186/s13722-015-0035-4] [Medline: 26016484]

123. Woodward A, Fyfe M, Handuleh J, Patel P, Godman B, Leather A, et al. Diffusion of e-health innovations in 'post-conflict' settings: a qualitative study on the personal experiences of health workers. Hum Resour Health 2014 Apr 23;12:22 [FREE Full text] [doi: 10.1186/1478-4491-12-22] [Medline: 24754997]

124. Al-Qirim N. Championing telemedicine adoption and utilization in healthcare organizations in New Zealand. Int $\mathrm{J}$ Med Inform 2007 Jan;76(1):42-54. [doi: 10.1016/j.ijmedinf.2006.02.001] [Medline: 16621682]

125. Alaboudi A, Atkins A, Sharp B, Balkhair A, Alzahrani M, Sunbul T. Barriers and challenges in adopting Saudi telemedicine network: the perceptions of decision makers of healthcare facilities in Saudi Arabia. J Infect Public Health 2016;9(6):725-733 [FREE Full text] [doi: 10.1016/j.jiph.2016.09.001] [Medline: 27649882]

126. Chronaki CE, Vardas P. Remote monitoring costs, benefits, and reimbursement: a European perspective. Europace 2013 Jun;15 Suppl 1:i59-i64. [doi: 10.1093/europace/eut110] [Medline: 23737233]

127. Coustasse A, Deslich S, Bailey D, Hairston A, Paul D. A business case for tele-intensive care units. Perm J 2014;18(4):76-84 [FREE Full text] [doi: 10.7812/TPP/14-004] [Medline: 25662529]

128. Cusack CM, Pan E, Hook JM, Vincent A, Kaelber DC, Middleton B. The value proposition in the widespread use of telehealth. J Telemed Telecare 2008;14(4):167-168. [doi: 10.1258/jtt.2007.007043] [Medline: 18534947]

129. DeWorsop D, Creatura G, Bluez G, Thurnauer H, Forselius-Bielen K, Ranganathan M, et al. Feasibility and success of cell-phone assisted remote observation of medication adherence (CAROMA) in clinical trials. Drug Alcohol Depend 2016 Dec 01;163:24-30. [doi: 10.1016/j.drugalcdep.2016.02.045] [Medline: 27068252]

130. Gabriel MH, Jones EB, Samy L, King J. Progress and challenges: implementation and use of health information technology among critical-access hospitals. Health Aff (Millwood) 2014 Jul;33(7):1262-1270. [doi: 10.1377/hlthaff.2014.0279] [Medline: 25006155]

131. Pan E, Cusack C, Hook J, Vincent A, Kaelber DC, Bates DW, et al. The value of provider-to-provider telehealth. Telemed J E Health 2008 Jun;14(5):446-453. [doi: 10.1089/tmj.2008.0017] [Medline: 18578679]

132. Rozenblum R, Jang Y, Zimlichman E, Salzberg C, Tamblyn M, Buckeridge D, et al. A qualitative study of Canada's experience with the implementation of electronic health information technology. CMAJ 2011 Mar 22;183(5):E281-E288 [FREE Full text] [doi: 10.1503/cmaj.100856] [Medline: 21343262]

133. Lee ACW, Billings M. Telehealth implementation in a skilled nursing facility: case report for physical therapist practice in Washington. Phys Ther 2016 Feb;96(2):252-259. [doi: 10.2522/ptj.20150079] [Medline: 26658151]

134. Abramson EL, Silver M, Kaushal R. Meaningful use status and participation in health information exchange among New York State hospitals: a longitudinal assessment. Jt Comm J Qual Patient Saf 2014 Oct;40(10):452-453. [Medline: 26111305]

135. Achey M, Aldred JL, Aljehani N, Bloem BR, Biglan KM, Chan P, International Parkinson and Movement Disorder Society Telemedicine Task Force. The past, present, and future of telemedicine for Parkinson's disease. Mov Disord 2014 Jun;29(7):871-883. [doi: 10.1002/mds.25903] [Medline: 24838316]

136. Al-Qirim NAY. Teledermatology: the case of adoption and diffusion of telemedicine health Waikato in New Zealand. Telemed J E Health 2003;9(2):167-177. [doi: 10.1089/153056203766437507] [Medline: 12855039]

137. Ayatollahi H, Mirani N, Haghani H. Electronic health records: what are the most important barriers? Perspect Health Inf Manag 2014;11:1c [FREE Full text] [Medline: 25593569]

138. Burke BL, Hall RW, Section on Telehealth Care. Telemedicine: pediatric applications. Pediatrics 2015 Jul;136(1):e293-e308 [FREE Full text] [doi: 10.1542/peds.2015-1517] [Medline: 26122813]

139. Driessen J, Castle NG, Handler SM. Perceived benefits, barriers, and drivers of telemedicine from the perspective of skilled nursing facility administrative staff stakeholders. J Appl Gerontol 2018 Jan;37(1):110-120. [doi: 10.1177/0733464816651884] [Medline: 27269289]

140. O'Toole LJ, Slade CP, Brewer GA, Gase LN. Barriers and facilitators to implementing primary stroke center policy in the United States: results from 4 case study states. Am J Public Health 2011 Mar;101(3):561-566. [doi: 10.2105/AJPH.2010.197954] [Medline: 21233430]

141. de Bustos EM, Vuillier F, Chavot D, Moulin T. Telemedicine in stroke: organizing a network--rationale and baseline principles. Cerebrovasc Dis 2009;27 Suppl 4:1-8. [doi: 10.1159/000213052] [Medline: 19546535]

142. Kulcsar M, Gilchrist S, George MG. Improving stroke outcomes in rural areas through telestroke programs: an examination of barriers, facilitators, and state policies. Telemed J E Health 2014 Jan;20(1):3-10. [doi: 10.1089/tmj.2013.0048] [Medline: 24286197]

143. Rogove HJ, McArthur D, Demaerschalk BM, Vespa PM. Barriers to telemedicine: survey of current users in acute care units. Telemed J E Health 2012;18(1):48-53. [doi: 10.1089/tmj.2011.0071] [Medline: 22082107] 
144. Cho I, Kim J, Kim JH, Kim HY, Kim Y. Design and implementation of a standards-based interoperable clinical decision support architecture in the context of the Korean EHR. Int J Med Inform 2010 Sep;79(9):611-622. [doi: 10.1016/j.ijmedinf.2010.06.002] [Medline: 20620098]

145. Alajlani M, Clarke M. Effect of culture on acceptance of telemedicine in Middle Eastern countries: case study of Jordan and Syria. Telemed J E Health 2013 Apr;19(4):305-311. [doi: 10.1089/tmj.2012.0106] [Medline: 23540280]

146. Adler-Milstein J, Sarma N, Woskie LR, Jha AK. A comparison of how four countries use health IT to support care for people with chronic conditions. Health Aff (Millwood) 2014 Sep;33(9):1559-1566. [doi: 10.1377/hlthaff.2014.0424] [Medline: 25201660]

147. Mettler T. Anticipating mismatches of HIT investments: Developing a viability-fit model for e-health services. Int J Med Inform 2016 Jan;85(1):104-115. [doi: 10.1016/j.ijmedinf.2015.10.002] [Medline: 26526279]

148. Stevenson P, Finnane AR, Soyer HP. Teledermatology and clinical photography: safeguarding patient privacy and mitigating medico-legal risk. Med J Aust 2016 Mar 21;204(5):198-200e1. [Medline: 26985853]

149. Mozer R, Bradford NK, Caffery LJ, Smith AC. Identifying perceived barriers to videoconferencing by rehabilitation medicine providers. J Telemed Telecare 2015 Dec;21(8):479-484. [doi: 10.1177/1357633X15607136] [Medline: 26556061]

150. Alkhaldi B, Sahama T, Huxley C, Gajanayake R. Barriers to implementing eHealth: a multi-dimensional perspective. Stud Health Technol Inform 2014;205:875-879. [Medline: 25160313]

151. Alsulame K, Khalifa M, Househ M. eHealth in Saudi Arabia: current trends, challenges and recommendations. Stud Health Technol Inform 2015;213:233-236. [Medline: 26153002]

152. Detmer D, Bloomrosen M, Raymond B, Tang P. Integrated personal health records: transformative tools for consumer-centric care. BMC Med Inform Decis Mak 2008;8:45 [FREE Full text] [doi: 10.1186/1472-6947-8-45] [Medline: 18837999]

153. Dixon BE, Simonaitis L, Goldberg HS, Paterno MD, Schaeffer M, Hongsermeier T, et al. A pilot study of distributed knowledge management and clinical decision support in the cloud. Artif Intell Med 2013 Sep;59(1):45-53. [doi: 10.1016/j.artmed.2013.03.004] [Medline: 23545327]

154. May C, Harrison R, Finch T, MacFarlane A, Mair F, Wallace P, Telemedicine Adoption Study Group. Understanding the normalization of telemedicine services through qualitative evaluation. J Am Med Inform Assoc 2003;10(6):596-604 [FREE Full text] [doi: 10.1197/jamia.M1145] [Medline: $\underline{12925553}$ ]

155. Owens DK. Use of medical informatics to implement and develop clinical practice guidelines. West J Med 1998 Mar;168(3):166-175 [FREE Full text] [Medline: 9549415]

156. Patel RN, Antonarakis GS. Factors influencing the adoption and implementation of teledentistry in the UK, with a focus on orthodontics. Community Dent Oral Epidemiol 2013 Oct;41(5):424-431. [doi: 10.1111/cdoe.12029] [Medline: 23240902]

157. Dinesen B, Nonnecke B, Lindeman D, Toft E, Kidholm K, Jethwani K, et al. Personalized telehealth in the future: a global research agenda. J Med Internet Res 2016 Mar 01;18(3):e53 [FREE Full text] [doi: 10.2196/jmir.5257] [Medline: 26932229]

158. Hawker F, Kavanagh S, Yellowlees P, Kalucy RS. Telepsychiatry in South Australia. J Telemed Telecare 1998;4(4):187-194. [doi: 10.1258/1357633981932181] [Medline: 10505352]

159. Lanzola G, Toffanin C, Di Palma F, Del Favero S, Magni L, Bellazzi R. Designing an artificial pancreas architecture: the AP@home experience. Med Biol Eng Comput 2015 Dec;53(12):1271-1283. [doi: 10.1007/s11517-014-1231-1] [Medline: 25430423]

160. May C. Mobilising modern facts: health technology assessment and the politics of evidence. Sociol Health Illn 2006 Jul;28(5):513-532 [FREE Full text] [doi: 10.1111/j.1467-9566.2006.00505.x] [Medline: 16910945$]$

161. Zelmer J, Hagens S. Understanding the gap between desire for and use of consumer health solutions. Healthc Pap 2014;13(4):9-21. [Medline: 25148119]

162. Cook DJ, Doolittle GC, Ferguson D, Hanks N, Hood J, Howard M, et al. Explaining the adoption of telemedicine services: an analysis of a paediatric telemedicine service. J Telemed Telecare 2002;8 Suppl 2:106-107. [doi: 10.1177/1357633X020080S248] [Medline: 12217159]

163. Menachemi N, Burke DE, Ayers DJ. Factors affecting the adoption of telemedicine--a multiple adopter perspective. J Med Syst 2004 Dec;28(6):617-632. [Medline: 15615290]

164. Kierkegaard P. Interoperability after deployment: persistent challenges and regional strategies in Denmark. Int J Qual Health Care 2015 Apr;27(2):147-153. [doi: 10.1093/intqhe/mzv009] [Medline: 25699549]

165. Doupi P. Evolving health IT systems evaluation: the convergence of health informatics and HTA. Stud Health Technol Inform 2016;222:220-236. [Medline: 27198105]

166. Gagnon M, Duplantie J, Fortin J, Landry R. Implementing telehealth to support medical practice in rural/remote regions: what are the conditions for success? Implement Sci 2006 Aug 24;1:18 [FREE Full text] [doi: 10.1186/1748-5908-1-18] [Medline: 16930484$]$

167. LeRouge C, Garfield MJ. Crossing the telemedicine chasm: have the U.S. barriers to widespread adoption of telemedicine been significantly reduced? Int J Environ Res Public Health 2013 Nov 28;10(12):6472-6484 [FREE Full text] [doi: 10.3390/ijerph10126472] [Medline: 24287864]

168. Varsi C, Ekstedt M, Gammon D, Ruland CM. Using the consolidated framework for implementation research to identify barriers and facilitators for the implementation of an internet-based patient-provider communication service in five settings: 
a qualitative study. J Med Internet Res 2015 Nov 18;17(11):e262 [FREE Full text] [doi: 10.2196/jmir.5091] [Medline: 26582138]

169. Charani E, Kyratsis Y, Lawson W, Wickens H, Brannigan ET, Moore LSP, et al. An analysis of the development and implementation of a smartphone application for the delivery of antimicrobial prescribing policy: lessons learnt. J Antimicrob Chemother 2013 Apr;68(4):960-967 [FREE Full text] [doi: 10.1093/jac/dks492] [Medline: 23258314]

170. Bouamrane M, Mair FS. Implementation of an integrated preoperative care pathway and regional electronic clinical portal for preoperative assessment. BMC Med Inform Decis Mak 2014 Nov 19;14:93 [FREE Full text] [doi: 10.1186/1472-6947-14-93] [Medline: 25407812]

171. Bullard MJ, Emond SD, Graham TAD, Ho K, Holroyd BR. Informatics and knowledge translation. Acad Emerg Med 2007 Nov;14(11):996-1002 [FREE Full text] [doi: 10.1197/j.aem.2007.06.032] [Medline: 17967961]

172. Umali E, McCool J, Whittaker R. Possibilities and expectations for mHealth in the Pacific Islands: insights from key informants. JMIR Mhealth Uhealth 2016 Jan;4(1):e9 [FREE Full text] [doi: 10.2196/mhealth.4626] [Medline: 26792386]

173. Hernández V, Blanquer I. The Grid as a healthcare provision tool. Methods Inf Med 2005;44(2):144-148. [Medline: 15924164]

174. Sweet LE, Moulaison HL. Electronic health records data and metadata: challenges for big data in the United States. Big Data 2013 Dec;1(4):245-251. [doi: 10.1089/big.2013.0023] [Medline: 27447257]

175. Wake DJ, He J, Czesak AM, Mughal F, Cunningham SG. MyDiabetesMyWay: an evolving national data driven diabetes self-management platform. J Diabetes Sci Technol 2016 Dec;10(5):1050-1058 [FREE Full text] [doi: 10.1177/1932296816648168] [Medline: 27162192]

176. Bond CS. Telehealth as a tool for independent self-management by people living with long term conditions. Stud Health Technol Inform 2014;206:1-6. [Medline: 25365666]

177. Bond CS, Worswick L. Self management and telehealth: lessons learnt from the evaluation of a Dorset telehealth program. Patient 2015 Aug;8(4):311-316. [doi: 10.1007/s40271-014-0091-y] [Medline: 25315192]

178. Camerini L, Camerini A, Schulz PJ. Do participation and personalization matter? A model-driven evaluation of an Internet-based patient education intervention for fibromyalgia patients. Patient Educ Couns 2013 Aug;92(2):229-234. [doi: 10.1016/j.pec.2013.04.007] [Medline: 23664234]

179. Fergie G, Hunt K, Hilton S. Social media as a space for support: young adults' perspectives on producing and consuming user-generated content about diabetes and mental health. Soc Sci Med 2016 Dec;170:46-54 [FREE Full text] [doi: 10.1016/j.socscimed.2016.10.006] [Medline: 27750067]

180. Griebel L, Sedlmayr B, Prokosch H, Criegee-Rieck M, Sedlmayr M. Key factors for a successful implementation of personalized e-health services. Stud Health Technol Inform 2013;192:965. [Medline: 23920739]

181. Schwarz F, Ward J, Willcock S. E-Health readiness in outback communities: an exploratory study. Rural Remote Health 2014;14(3):2871 [FREE Full text] [Medline: 25190566]

182. Tran BQ, Buckley KM, Bertera EM, Gonzales PL. Benefits \& barriers to adoption of health IT in an elderly low-income, minority community-based environment. Conf Proc IEEE Eng Med Biol Soc 2009;2009:6441-6443. [doi: 10.1109/IEMBS.2009.5333537] [Medline: 19964428]

183. Duman-Lubberding S, van Uden-Kraan CF, Peek N, Cuijpers P, Leemans CR, Verdonck-de Leeuw IM. An eHealth application in head and neck cancer survivorship care: health care professionals' perspectives. J Med Internet Res 2015 Oct 21;17(10):e235 [FREE Full text] [doi: 10.2196/jmir.4870] [Medline: 26489918]

184. Peng W, Yuan S, Holtz BE. Exploring the challenges and opportunities of health mobile apps for individuals with type 2 diabetes living in rural communities. Telemed J E Health 2016 Sep;22(9):733-738. [doi: 10.1089/tmj.2015.0180] [Medline: 26982017]

185. Ronda MCM, Dijkhorst-Oei L, Rutten GEHM. Reasons and barriers for using a patient portal: survey among patients with diabetes mellitus. J Med Internet Res 2014;16(11):e263 [FREE Full text] [doi: 10.2196/jmir.3457] [Medline: 25424228]

186. Sanders C, Rogers A, Bowen R, Bower P, Hirani S, Cartwright M, et al. Exploring barriers to participation and adoption of telehealth and telecare within the Whole System Demonstrator trial: a qualitative study. BMC Health Serv Res 2012;12:220 [FREE Full text] [doi: 10.1186/1472-6963-12-220] [Medline: 22834978]

187. Vriend I, Coehoorn I, Verhagen E. Implementation of an app-based neuromuscular training programme to prevent ankle sprains: a process evaluation using the RE-AIM Framework. Br J Sports Med 2015 Apr;49(7):484-488. [doi: 10.1136/bjsports-2013-092896] [Medline: 24470587]

188. Hanna L, May C, Fairhurst K. Non-face-to-face consultations and communications in primary care: the role and perspective of general practice managers in Scotland. Inform Prim Care 2011;19(1):17-24 [FREE Full text] [Medline: 22118332]

189. Tang PC, Ash JS, Bates DW, Overhage JM, Sands DZ. Personal health records: definitions, benefits, and strategies for overcoming barriers to adoption. J Am Med Inform Assoc 2006;13(2):121-126 [FREE Full text] [doi: 10.1197/jamia.M2025] [Medline: 16357345]

190. Gagnon M, Ngangue P, Payne-Gagnon J, Desmartis M. m-Health adoption by healthcare professionals: a systematic review. J Am Med Inform Assoc 2016 Jan;23(1):212-220. [doi: 10.1093/jamia/ocv052] [Medline: 26078410] 
191. Harvey J, Dopson S, McManus RJ, Powell J. Factors influencing the adoption of self-management solutions: an interpretive synthesis of the literature on stakeholder experiences. Implement Sci 2015 Nov 13;10:159 [FREE Full text] [doi: 10.1186/s13012-015-0350-x] [Medline: 26566623]

192. Zhang X, Yu P, Yan J, Ton AMSI. Using diffusion of innovation theory to understand the factors impacting patient acceptance and use of consumer e-health innovations: a case study in a primary care clinic. BMC Health Serv Res 2015 Feb 21;15:71 [FREE Full text] [doi: 10.1186/s12913-015-0726-2] [Medline: 25885110]

193. Lober WB, Quiles C, Wagner S, Cassagnol R, Lamothes R, Alexis DRP, et al. Three years experience with the implementation of a networked electronic medical record in Haiti. AMIA Annu Symp Proc 2008 Nov 06:434-438 [FREE Full text] [Medline: 18999283]

194. Mitchell JG. The uneven diffusion of telemedicine services in Australia. J Telemed Telecare 1999;5 Suppl 1:S45-S47. [Medline: 10534838$]$

195. Taylor J, Coates L. Caring from a distance: the role of telehealth. Nurs Times 2015;111(28-29):18-20. [Medline: 26477231]

196. Moxham C, Chambers N, Girling J, Garg S, Jelfs E, Bremner J. Perspectives on the enablers of e-heath adoption: an international interview study of leading practitioners. Health Serv Manage Res 2012 Aug;25(3):129-137. [doi: 10.1258/hsmr.2012.012018] [Medline: 23135887]

197. Paré G, Trudel M. Knowledge barriers to PACS adoption and implementation in hospitals. Int J Med Inform 2007 Jan;76(1):22-33. [doi: 10.1016/j.ijmedinf.2006.01.004] [Medline: 16478675]

198. Vimarlund V, Le Rouge C. Barriers and opportunities to the widespread adoption of telemedicine: a bi-country evaluation. Stud Health Technol Inform 2013;192:933. [Medline: 23920707]

199. Nicholas J, Boydell K, Christensen H. mHealth in psychiatry: time for methodological change. Evid Based Ment Health 2016 Dec;19(2):33-34. [doi: 10.1136/eb-2015-102278] [Medline: 27044849]

200. Meyer R. A bio-medical informatics perspective on human factors: how human factors influence adoption of healthcare information technology. Yearb Med Inform 2010:21-24. [Medline: 20938565]

201. Murray E. Web-based interventions for behavior change and self-management: potential, pitfalls, and progress. Med 20 2012;1(2):e3 [FREE Full text] [doi: 10.2196/med20.1741] [Medline: 25075231]

202. Cimperman M, Brenčič MM, Trkman P, Stanonik MDL. Older adults' perceptions of home telehealth services. Telemed J E Health 2013 Oct;19(10):786-790 [FREE Full text] [doi: 10.1089/tmj.2012.0272] [Medline: 23931702]

203. de Tolly KM, Constant D. Integrating mobile phones into medical abortion provision: intervention development, use, and lessons learned from a randomized controlled trial. JMIR Mhealth Uhealth 2014;2(1):e5 [FREE Full text] [doi: 10.2196/mhealth.3165] [Medline: 25098569]

204. van Deursen AJ, van Dijk JA. Internet skills performance tests: are people ready for eHealth? J Med Internet Res 2011 Apr;13(2):e35 [FREE Full text] [doi: 10.2196/jmir.1581] [Medline: 21531690]

205. Bielli E, Carminati F, La Capra S, Lina M, Brunelli C, Tamburini M. A wireless health outcomes monitoring system (WHOMS): development and field testing with cancer patients using mobile phones. BMC Med Inform Decis Mak 2004 Jun 15;4:7 [FREE Full text] [doi: 10.1186/1472-6947-4-7] [Medline: 15196308]

206. Young R, Willis E, Cameron G, Geana M. "Willing but unwilling": attitudinal barriers to adoption of home-based health information technology among older adults. Health Informatics J 2014 Jun;20(2):127-135. [doi: 10.1177/1460458213486906] [Medline: 24056750]

207. Armer JM, Harris K, Dusold JM. Application of the concerns-based adoption model to the installation of telemedicine in a rural Missouri nursing home. J Nurses Staff Dev 2004;20(1):42-49. [Medline: 15076128]

208. Plaete J, Crombez G, DeSmet A, Deveugele M, Verloigne M, De Bourdeaudhuij I. What do general practitioners think about an online self-regulation programme for health promotion? Focus group interviews. BMC Fam Pract 2015;16(1):3 [FREE Full text] [doi: 10.1186/s12875-014-0214-5] [Medline: 25608851]

209. Villalba-Mora E, Casas I, Lupiañez-Villanueva F, Maghiros I. Adoption of health information technologies by physicians for clinical practice: the Andalusian case. Int J Med Inform 2015 Jul;84(7):477-485. [doi: 10.1016/j.ijmedinf.2015.03.002] [Medline: 25823578]

210. DeLuca JM, Enmark R. E-health: the changing model of healthcare. Front Health Serv Manage 2000;17(1):3-15. [Medline: 11184427]

211. Baumel A, Muench F. Heuristic evaluation of Ehealth interventions: establishing standards that relate to the therapeutic process perspective. JMIR Ment Health 2016 Jan 13;3(1):e5 [FREE Full text] [doi: 10.2196/mental.4563] [Medline: 26764209]

212. Hsieh H, Tsai C, Chih W, Lin H. Factors affecting success of an integrated community-based telehealth system. Technol Health Care 2015;23 Suppl 2:S189-S196. [doi: 10.3233/THC-150953] [Medline: 26410483]

213. Quinlivan JA, Lyons S, Petersen RW. Attitudes of pregnant women towards personally controlled electronic, hospital-held, and patient-held medical record systems: a survey study. Telemed J E Health 2014 Sep;20(9):810-815. [doi: 10.1089/tmj.2013.0342] [Medline: 25046543]

214. Bruns NE, Irtan S, Rothenberg SS, Bogen EM, Kotobi H, Ponsky TA. Trans-Atlantic telementoring with pediatric surgeons: technical considerations and lessons learned. J Laparoendosc Adv Surg Tech A 2016 Jan;26(1):75-78. [doi:

10.1089/lap.2015.0131] [Medline: 26698191] 
215. Mars M. Health capacity development through telemedicine in Africa. Yearb Med Inform 2010:87-93. [Medline: 20938578]

216. Ruxwana N, Herselman M, Pottas D. A Generic Quality Assurance Model (GQAM) for successful e-health implementation in rural hospitals in South Africa. Health Inf Manag 2014;43(1):26-36. [Medline: 27010686]

217. Raisinghani MS, Young E. Personal health records: key adoption issues and implications for management. Int J Electron Healthc 2008;4(1):67-77. [doi: 10.1504/IJEH.2008.018921] [Medline: 18583296]

218. George S, Hamilton A, Baker RS. How do low-income urban African Americans and Latinos feel about telemedicine? A diffusion of innovation analysis. Int J Telemed Appl 2012;2012:715194 [FREE Full text] [doi: 10.1155/2012/715194] [Medline: 22997511]

219. Anvari M. Robot-assisted remote telepresence surgery. Semin Laparosc Surg 2004 Jun;11(2):123-128. [Medline: 15254651]

220. Gorini A, Gaggioli A, Vigna C, Riva G. A second life for eHealth: prospects for the use of 3-D virtual worlds in clinical psychology. J Med Internet Res 2008;10(3):e21 [FREE Full text] [doi: 10.2196/jmir.1029] [Medline: 18678557]

221. Obstfelder A, Engeseth KH, Wynn R. Characteristics of successfully implemented telemedical applications. Implement Sci 2007 Jul 27;2:25 [FREE Full text] [doi: 10.1186/1748-5908-2-25] [Medline: 17662134]

222. Nijland N, van Gemert-Pijnen JE, Boer H, Steehouder MF, Seydel ER. Increasing the use of e-consultation in primary care: results of an online survey among non-users of e-consultation. Int J Med Inform 2009 Oct;78(10):688-703. [doi: 10.1016/j.ijmedinf.2009.06.002] [Medline: 19625210]

223. Dadd M, Doyle B, Wilson L, Gunaratnam M. Lessons learned from the Hospital Without Walls project. J Telemed Telecare 2002;8 Suppl 3:S3:11-S3:14. [Medline: 12661607]

224. Cocosila M, Archer N. Perceptions of chronically ill and healthy consumers about electronic personal health records: a comparative empirical investigation. BMJ Open 2014 Jul 23;4(7):e005304 [FREE Full text] [doi: 10.1136/bmjopen-2014-005304] [Medline: 25056975]

225. Courtney KL. Privacy and senior willingness to adopt smart home information technology in residential care facilities. Methods Inf Med 2008;47(1):76-81. [Medline: 18213432]

226. Barbieri JS, Nelson CA, Bream KD, Kovarik CL. Primary care providers' perceptions of mobile store-and-forward teledermatology. Dermatol Online J 2015 Aug 15;21(8). [Medline: 26437165]

227. Courtney KL, Demiris G, Rantz M, Skubic M. Needing smart home technologies: the perspectives of older adults in continuing care retirement communities. Inform Prim Care 2008;16(3):195-201 [FREE Full text] [Medline: 19094406]

228. Wilkowska W, Ziefle M. Privacy and data security in E-health: requirements from the user's perspective. Health Informatics J 2012 Sep;18(3):191-201. [doi: 10.1177/1460458212442933] [Medline: 23011814]

229. Driessen J, Bonhomme A, Chang W, Nace DA, Kavalieratos D, Perera S, et al. Nursing home provider perceptions of telemedicine for reducing potentially avoidable hospitalizations. J Am Med Dir Assoc 2016 Jun 01;17(6):519-524 [FREE Full text] [doi: 10.1016/j.jamda.2016.02.004] [Medline: 26969534]

230. McGraw D, Dempsey JX, Harris L, Goldman J. Privacy as an enabler, not an impediment: building trust into health information exchange. Health Aff (Millwood) 2009;28(2):416-427 [FREE Full text] [doi: 10.1377/hlthaff.28.2.416] [Medline: 19275998]

231. Zanaboni P, Knarvik U, Wootton R. Adoption of routine telemedicine in Norway: the current picture. Glob Health Action 2014;7:22801 [FREE Full text] [Medline: 24433942]

232. Martin AB, Probst JC, Shah K, Chen Z, Garr D. Differences in readiness between rural hospitals and primary care providers for telemedicine adoption and implementation: findings from a statewide telemedicine survey. J Rural Health 2012 Jan;28(1):8-15. [doi: 10.1111/j.1748-0361.2011.00369.x] [Medline: 22236310]

233. Williams G, Doughty K, Bradley DA. Safety and risk issues in using telecare. J Telemed Telecare 2000;6(5):249-262. [doi: 10.1258/1357633001935833] [Medline: 11070585]

234. Lewis T, Synowiec C, Lagomarsino G, Schweitzer J. E-health in low- and middle-income countries: findings from the Center for Health Market Innovations. Bull World Health Organ 2012 May 1;90(5):332-340 [FREE Full text] [doi: 10.2471/BLT.11.099820] [Medline: 22589566]

235. De Simone A, Leoni L, Luzi M, Amellone C, Stabile G, La Rocca V, et al. Remote monitoring improves outcome after ICD implantation: the clinical efficacy in the management of heart failure (EFFECT) study. Europace 2015 Aug;17(8):1267-1275. [doi: 10.1093/europace/euu318] [Medline: 25842271]

236. Lau AY, Arguel A, Dennis S, Liaw S, Coiera E. "Why Didn't it Work?" Lessons from a randomized controlled trial of a web-based personally controlled health management system for adults with asthma. J Med Internet Res 2015 Dec;17(12):e283 [FREE Full text] [doi: 10.2196/jmir.4734] [Medline: 26678294]

237. Hardisty AR, Peirce SC, Preece A, Bolton CE, Conley EC, Gray WA, et al. Bridging two translation gaps: a new informatics research agenda for telemonitoring of chronic disease. Int J Med Inform 2011 Oct;80(10):734-744. [doi: 10.1016/j.ijmedinf.2011.07.002] [Medline: 21890403]

238. Naik AD, Lawrence B, Kiefer L, Ramos K, Utech A, Masozera N, et al. Building a primary care/research partnership: lessons learned from a telehealth intervention for diabetes and depression. Fam Pract 2015 Apr;32(2):216-223. [doi: 10.1093/fampra/cmu084] [Medline: 25552674] 
239. Poole ES. HCI and mobile health interventions: how human-computer interaction can contribute to successful mobile health interventions. Transl Behav Med 2013 Dec;3(4):402-405 [FREE Full text] [doi: 10.1007/s13142-013-0214-3] [Medline: 24294328]

240. Kruse CS, Regier V, Rheinboldt KT. Barriers over time to full implementation of health information exchange in the United States. JMIR Med Inform 2014;2(2):e26 [ [FREE Full text] [doi: 10.2196/medinform.3625] [Medline: 25600635]

241. Gardner RM. Computerized clinical decision-support in respiratory care. Respir Care 2004 Apr;49(4):378-86; discussion 386 [FREE Full text] [Medline: 15030611]

242. Kawamoto K, Houlihan CA, Balas EA, Lobach DF. Improving clinical practice using clinical decision support systems: a systematic review of trials to identify features critical to success. BMJ 2005 Apr 2;330(7494):765 [FREE Full text] [doi: 10.1136/bmj.38398.500764.8F] [Medline: 15767266]

243. Davis MM, Freeman M, Kaye J, Vuckovic N, Buckley DI. A systematic review of clinician and staff views on the acceptability of incorporating remote monitoring technology into primary care. Telemed J E Health 2014 May;20(5):428-438 [FREE Full text] [doi: 10.1089/tmj.2013.0166] [Medline: 24731239]

244. Bowens FM, Frye PA, Jones WA. Health information technology: integration of clinical workflow into meaningful use of electronic health records. Perspect Health Inf Manag 2010 Oct 01;7:1d [FREE Full text] [Medline: 21063545]

245. LeTourneau B. Managing physician resistance to change. J Healthc Manag 2004;49(5):286-288. [Medline: 15499802$]$

246. Narine L, Persaud DD. Gaining and maintaining commitment to large-scale change in healthcare organizations. Health Serv Manage Res 2003 Aug;16(3):179-187. [doi: 10.1258/095148403322167933] [Medline: 12908992]

247. Appelbaum SH, Wohl L. Transformation or change: some prescriptions for health care organizations. Manag Serv Q 2000 Oct;10(5):279-298. [doi: 10.1108/09604520010345768]

248. Pardo del Val M, Martínez Fuentes C. Resistance to change: a literature review and empirical study. Manag Decis 2003 Mar;41(2):148-155. [doi: 10.1108/00251740310457597]

249. Landaeta RE, Mun JH, Rabadi G, Levin D. Identifying sources of resistance to change in healthcare. Int J Healthc Technol Manag 2008;9(1):74. [doi: 10.1504/IJHTM.2008.016849]

250. Hickson R, Talbert J, Thornbury WC, Perin NR, Goodin AJ. Online medical care: the current state of "eVisits" in acute primary care delivery. Telemed J E Health 2015 Feb;21(2):90-96. [doi: 10.1089/tmj.2014.0022] [Medline: 25474083]

251. Declerck G, Aimé X. Reasons (not) to spend a few billions more on EHRs: how human factors research can help. Yearb Med Inform 2014 Aug 15;9:90-96 [FREE Full text] [doi: 10.15265/IY-2014-0033] [Medline: 25123727]

252. Frauenberger C, Good J, Fitzpatrick G, Iversen OS. In pursuit of rigour and accountability in participatory design. Int $\mathbf{J}$ Hum Comput Stud 2015 Feb;74:93-106 [FREE Full text] [doi: 10.1016/j.ijhcs.2014.09.004] [Medline: 26109833]
Abbreviations
MeSH: Medical Subject Heading
PICO: patient, intervention, comparison, and outcome
PRISMA: Preferred Reporting Items for Systematic reviews and Meta-Analyses

\author{
Edited by G Eysenbach; submitted 28.02.18; peer-reviewed by I Mircheva; accepted 09.04.18; published 01.05.18 \\ Please cite as: \\ Granja C, Janssen W, Johansen $M A$ \\ Factors Determining the Success and Failure of eHealth Interventions: Systematic Review of the Literature \\ J Med Internet Res 2018;20(5):e10235 \\ URL: http://www.jmir.org/2018/5/e10235/ \\ doi: $\underline{10.2196 / 10235}$ \\ PMID: 29716883
}

(C)Conceição Granja, Wouter Janssen, Monika Alise Johansen. Originally published in the Journal of Medical Internet Research (http://www.jmir.org), 01.05.2018. This is an open-access article distributed under the terms of the Creative Commons Attribution License (https://creativecommons.org/licenses/by/4.0/), which permits unrestricted use, distribution, and reproduction in any medium, provided the original work, first published in the Journal of Medical Internet Research, is properly cited. The complete bibliographic information, a link to the original publication on http://www.jmir.org/, as well as this copyright and license information must be included. 